\title{
Transcriptional profiling of ErbB signalling in mammary luminal epithelial cells - interplay of ErbB and IGF1 signalling through IGFBP3 regulation
}

\author{
Jenny Worthington ${ }^{1 \dagger}$, Mariana Bertani ${ }^{2+}$, Hong-Lin Chan ${ }^{3}$, Bertran Gerrits ${ }^{2}$, John F Timms ${ }^{1 *}$
}

\begin{abstract}
Background: Members of the ErbB family of growth factor receptors are intricately linked with epithelial cell biology, development and tumourigenesis; however, the mechanisms involved in their downstream signalling are poorly understood. Indeed, it is unclear how signal specificity is achieved and the relative contribution each receptor has to specific gene expression.

Methods: Gene expression profiling of a human mammary luminal epithelial cell model of ErbB2-overexpression was carried out using CDNA microarrays with a common RNA reference approach to examine long-term overlapping and differential responses to EGF and heregulin beta1 treatment in the context of ErbB2 overexpression. Altered gene expression was validated using quantitative real time PCR and/or immunoblotting. One gene of interest was targeted for further characterisation, where the effects of siRNA-mediated silencing on IGF1-dependent signalling and cellular phenotype were examined and compared to the effects of loss of ErbB2 expression.
\end{abstract}

Results: 775 genes were differentially expressed and clustered in terms of their growth factor responsiveness. As well as identifying uncharacterized genes as novel targets of ErbB2-dependent signalling, ErbB2 overexpression augmented the induction of multiple genes involved in proliferation (e.g. MYC, MAP2K1, MAP2K3), autocrine growth factor signalling (VEGF, PDGF) and adhesion/cytoskeletal regulation (ZYX, THBS1, VCL, CNN3, ITGA2, ITGA3, NEDD9, TAGLN), linking them to the hyper-poliferative and altered adhesive phenotype of the ErbB2-

overexpressing cells. We also report ErbB2-dependent down-regulation of multiple interferon-stimulated genes that may permit ErbB2-overexpressing cells to resist the anti-proliferative action of interferons. Finally, IGFBP3 was unique in its pattern of regulation and we further investigated a possible role for IGFBP3 down-regulation in ErbB2dependent transformation through suppressed IGF1 signalling. We show that IGF1-dependent signalling and proliferation were enhanced in ErbB2-overexpressing cells, whilst loss of ErbB2 expression by siRNA silencing reduced IGF1 signalling. Furthermore, IGFBP3 knockdown resulted in basal ERK and Akt activation in luminal epithelial cells and increased invasiveness and anchorage-independent colony formation in SKBR3 cells.

Conclusions: These data show IGFBP3 as a negative regulator of transformation and that its down-regulation enhances IGF1-dependent signalling. They also show that ErbB2 can up-regulate IGF1-dependent signalling, possibly via the regulated expression of IGFBP3.

\footnotetext{
* Correspondence: jtimms@wibr.ucl.ac.uk

+ Contributed equally

'Cancer Proteomics Laboratory, EGA Institute for Women's Health, University

College London, Cruciform Building, Gower Street, London, WC1E 6BT, UK

Full list of author information is available at the end of the article
} 


\section{Background}

The expression and activity of the ErbB/HER family of receptor tyrosine kinases is frequently deregulated in human cancers. To date, four members of this family have been described: EGFR, ErbB2 (HER2), ErbB3 (HER3) and ErbB4 (HER4). Signalling through the ErbB family is initiated by ligand-induced receptor homo- or heterodimerzation leading to stimulation of the receptors' intrinsic tyrosine kinase activity and triggering of auto- and cross-phosphorylation of tyrosine residues creating docking sites for adaptor proteins and enzymes that initiate signal transduction events ultimately leading to changes in gene expression and altered cellular phenotype [1]. Numerous tumour, epithelial or stromal-derived growth factors (GFs) bind with different affinities and specificities to the different ErbB family members. These include: EGF, TGF $\alpha$ and amphiregulin (AREG), which bind specifically to EGFR; heparin-binding EGF-like growth factor, betacellulin and epiregulin which bind to both EGFR and ErbB4 [2]; and the neuregulins/heregulins (HRGs), which are specific for ErbB3 and ErbB4 [3]. Although ErbB2 is an orphan receptor with no ligand described to date, it is the preferred dimerzation partner of the other ErbB family members, acting as a potentiator of signalling and highlighting the importance of heterodimerzation within the ErbB family [3-6].

EGF and HRG can activate many intracellular signalling cascades and appear to exert distinct biological functions that depend on the nature of the receptor complexes induced. Although there is major overlap in the signalling pathways activated by ErbB receptors, specific family members can preferentially modulate distinct pathways. For instance, while all ErbB receptors activate the MAPK pathway via Shc and/or Grb2, ErbB3 is the most potent activator of PI3K signalling due to its multiple binding sites for the p85 regulatory subunit of PI3K $[7,8]$. In contrast, Eps15 and Cbl are both EGFRspecific substrates involved in receptor down-regulation $[9,10]$. The relative expression of each ErbB receptor influences the cellular response to their ligands. For example, cells expressing high levels of ErbB2 show a greater response to HRG and ErbB3 shows higher affinity for HRG when co-expressed with ErbB2 [11]. This preferential cooperativity extends to oncogenic transformation, with ErbB2-ErbB3 heterodimers reported as the most potent signalling activators [12,13]. Importantly, the aberrant expression and/or activation of ErbB family members have been reported in a number of different tumour types. In particular, there is an extensive literature on the role of ErbB receptors in breast cancer. ErbB2 is overexpressed in 25-30\% of all breast cancers due to gene amplification, and is correlated with disease progression, advanced tumour stage, decreased survival, poor response to therapy and metastasis $[14,15]$. Such poor prognosis is a likely reflection of the biological effects of ErbB2 overexpression, including increased cellular proliferation, anti-apoptosis, cell invasiveness and promotion of angiogenesis. The ErbB receptors have consequently become targets for specific anti-cancer therapies [16-20]. Indeed, one of these therapies, herceptin (trastuzumab), a monoclonal antibody against the extracellular domain of ErbB2, has shown significant clinical benefit for patients with ErbB2-positive breast cancers. Indeed, the combined results of several clinical trials have shown that the addition of 1 year of trastuzumab to adjuvant chemotherapy significantly improves disease-free survival by 33\%-52\% [21]. Despite this, less than $35 \%$ of patients respond to trastuzumab as a single agent and those who initially respond well generally acquire resistance within a year (reviewed in [22]). These data suggest that ErbB2 overexpression alone is not a reliable predictor of therapeutic outcome and that additional factors are involved. Thus, the identification and characterization of genes associated with ErbB2 overexpression would be beneficial, in order to better define the molecular mechanisms involved in ErbB2dependent transformation and to identify novel drug targets.

Recently, much effort has been put into tumour expression profiling in an attempt to characterize the genes involved in malignant transformation. Microarray analysis has been reported to successfully predict estrogen receptor and lymph-node status of breast cancer [23,24], to distinguish between cancers associated with BRCA1 or BRCA2 mutations [25] and to identify subclasses of breast cancer and predict outcome based on gene expression patterns [23,26-29]. Although these approaches are useful for identifying diagnostic and prognostic markers, few microarray studies have examined ligand-induced signalling events involved in transformation. The aim of this study was to use microarray analysis to investigate ErbB ligand-induced transcriptional responses and diversification of signalling events downstream of ErbB receptors in a human mammary luminal epithelial cell (HMLEC) model. This model comprises an SV40 large T antigen-immortalized HMLEC parental cell line derived from flow-sorted cells from reduction mammoplasty material and a derivative clone stably overexpressing ErbB2 [30,31]. The cells require serum for proliferation, the removal of which leads to loss of viability. In the absence of serum, treatment with the ErbB-specific ligands HRG 11 or EGF can support proliferation and survival, with the ErbB2-overexpressing cells displaying increased rates of proliferation, anchorageindependent growth and enhanced mitogenic signalling compared to the parental line [31,32]. In the present study, cells were serum-starved and treated with EGF or 
HRG $\beta 1$ over a timecourse to establish long-term HRGand EGF-specific transcriptional responses to examine diversification of signalling through EGFR and ErbB3 receptors and to assess how ErbB2 overexpression alters these responses.

\section{Methods}

Cell culture, growth factor stimulation and RNA isolation The parental HMLEC line HB4a and an ErbB2-overexpressing derivative C3.6 have been previously described $[31,32]$. Cells were cultured in RPMI-1640 media supplemented with $10 \%$ fetal calf serum (FCS), $2 \mathrm{mM}$ glutamine, $100 \mathrm{IU} / \mathrm{ml}$ penicillin, $100 \mu \mathrm{g} / \mathrm{ml}$ streptomycin, $5 \mu \mathrm{g} / \mathrm{ml}$ hydrocortisone and $5 \mu \mathrm{g} / \mathrm{ml}$ insulin (both Sigma) at $37^{\circ} \mathrm{C}$ in a $10 \% \mathrm{CO}_{2}$ humidified incubator. Before stimulation, HB4a and C3.6 cells were starved of GFs for $48 \mathrm{~h}$ in RPMI-1640 media with $0.1 \%$ FCS, $100 \mathrm{IU} / \mathrm{ml}$ penicillin, $100 \mu \mathrm{g} / \mathrm{ml}$ streptomycin and $5 \mu \mathrm{g} / \mathrm{ml}$ hydrocortisone. Cells were then treated with $1 \mathrm{nM}$ EGF or $1 \mathrm{nM}$ HRG $\beta 1$ (HRG hereafter) (both R\&D Systems) for $4 \mathrm{~h}, 18 \mathrm{~h}$ and $24 \mathrm{~h}$ prior to RNA isolation. Two plates were prepared for control (serum-starved) cells and for each time point. Total RNA was isolated using TRIZOL ${ }^{\mathrm{TM}}$ reagent (Invitrogen Life Technologies) according to the manufacturer's protocol. Each plate generated two samples of total RNA for reciprocal labelling, resulting in a total of four replicates for microarray experiments. Serum starved cells were also treated with $25 \mathrm{ng} / \mathrm{mL}$ IGF1 for the indicated times. SKBR3 cells were maintained in tissue culture flasks containing DMEM/F-12 medium supplemented with $10 \%$ (v/v) FCS, $100 \mu \mathrm{g} / \mathrm{mL}$ streptomycin and $100 \mathrm{IU} / \mathrm{mL}$ penicillin (Gibco-Invitrogen Corp) in a humidified incubator at $37^{\circ} \mathrm{C}$ with $5 \% \mathrm{CO}_{2}$.

\section{Microarray experimental design}

Hver 1.3.1 arrays used in this study were obtained from the Wellcome Trust Sanger Institute. Each microarray contains a redundant set of 9932 PCR-derived, sequence verified cDNA clones representing around 6,000 genes. $25 \mu \mathrm{g}$ of total RNA was used to produce labeled cDNA by anchored oligo(dT)-primed reverse transcription with Superscript II Reverse Transcriptase (Invitrogen Life Technologies) in the presence of Cy3- or Cy5-dUTP (Amersham Pharmacia). Unincorporated Cy dye was removed using Autosequ-50 Columns (Amersham Pharmacia) and repetitive DNA sequences were blocked by coprecipitation of labeled cDNA with $8 \mu \mathrm{g}$ Cot1 (Boehringer Mannheim) and $8 \mu \mathrm{g}$ poly(dA) DNA (Sigma). The labeled cDNA pellet was re-suspended in hybridization buffer $(4 \times$ SSC, 5× Denhardt's solution, $50 \mathrm{mM}$ Tris- $\mathrm{HCl} \mathrm{pH} \mathrm{7.6,}$ $0.1 \%$ sarkosyl, $49 \%$ formamide) and hybridized onto arrays at $47^{\circ} \mathrm{C}$ overnight. Slides were washed twice in $2 \times \mathrm{SSC}$, four times in $0.1 \times$ SSC plus $0.1 \%$ SDS, twice in $0.1 \times \mathrm{SSC}$ and then dried by centrifugation before scanning.
All samples were co-hybridized to a common standard reference comprised of total RNA pooled from cell line BT474 and two grade III invasive ductal breast carcinomas (gift of Dr Alan Mackay, ICR, London), allowing crosscomparison of multiple experimental conditions. A “dye-flip" approach was used to minimize dye-specific bias, where two biological replicates were labeled with $\mathrm{Cy} 3$ and hybridized with Cy5-labelled reference and vice versa (four replicates). For the 14 experimental conditions ( 2 cell lines, 2 GFs and 3 time points plus untreated), a total of 56 hybridizations were thus performed.

\section{Data normalization, filtering and analysis}

Slides were scanned using ScanArray 4000XL and spots quantified using QuantArray v3.0 (both Packard BioChip Technology). Cy-dye emission signals were scaled in QuantArray using the median intensity of each channel, and any visible hybridization artifacts were flagged and recorded as absent during data filtering and analysis. Data was background subtracted and exported to GeneSpring v6.1 (Silicon Genetics) for normalization. The fluorescence intensity ratio between each sample and the co-hybridized reference (sample/ref) was calculated and represents the expression level for a given probe on each individual replicate. The dataset was then normalized using the intensity-dependent LOWESS regression technique [33]. Normalized raw data and experimental details were processed to conform with Minimum Information About a Microarray Experiment (MIAME) guidelines and are deposited in the Array Express (http://www.ebi.ac.uk/arrayexpress) repository (accession number E-TABM-106). Genes were then filtered using the excel add-in SAM (Significant Analysis of Microarray) [34] to identify genes showing significant changes in expression by assigning a score on the basis of change in gene expression relative to the standard deviation of repeated measurements. A false discovery rate threshold of $3 \%$ was used as the cut-off to report differentially regulated genes. Averaged values for each of the 14 experimental conditions were then compared to identify genes that were up- or down-regulated generating a list of 775 genes that changed significantly between two or more experimental conditions. TIGR $\mathrm{MeV}$ software v2.2 (The Institute for Genomic Research) was used for clustering analysis of the 775 genes using two sets of average ratios: i) the HB4a/C3.6 ratio was taken at each time point for ErbB2-dependent changes in gene expression, and ii) the $\mathrm{T} / \mathrm{T} 0$ ratio was taken in each cell line for GF-dependent changes in gene expression. Values were log2 transformed, loaded into TIGR MeV for average-linkage hierarchical clustering using Euclidian Distance and for $k$-means clustering using $4(k)$ groups. Genes in each group were then subjected to hierarchical clustering. 


\section{Semi-quantitative Real Time-PCR}

Samples were generated by reverse transcription of $2.5 \mu \mathrm{g}$ of total RNA using Superscript II Reverse Transcriptase (Invitrogen Life Technologies) and random hexamer primers (Applied Biosystems). cDNAs were then treated with RNase H (Invitrogen Life Technologies) to eliminate RNA contamination. Real Time-PCR (qRT-PCR) was performed using the Assay-on-Demand system (Applied Biosystems) according to the manufacturer's protocol. Assay IDs were: Hs99999905_m1 (GAPDH); Hs99999901_s1 (18S); Hs00155832_m1 (AREG); Hs00426287_m1 (IGFBP3); Hs00192713_m1 (G1P2); Hs00175188_m1 (CTSC); Hs00196051_m1 (ISGF3G); Hs00242943_m1 (OAS1); Hs00195584_m1 (S100P); Hs00602835_s1 (SFN); Hs00173626_m1 (VEGF); Hs00185574_m1 (VIL2); Hs00185584_m1(VIM); Hs00170299_m1 (ZYX). Briefly, primer and probe mix was added to PCR Master Mix with $1 \mu \mathrm{L}$ of cDNA per $50 \mu \mathrm{L}$ reaction. Sample fluorescence emission was recorded for each cycle on an ABI7700 Sequence Detection System. Cycling conditions were as follows: initial enzyme activation step at $95^{\circ} \mathrm{C}$ for $10 \mathrm{~min}$ and then 39 repeating cycles of $95^{\circ} \mathrm{C}$ for $10 \mathrm{sec}$ and $60^{\circ} \mathrm{C}$ for $1 \mathrm{~min}$. Serial dilution experiments of each primer against the endogenous control were prepared to test for amplification efficiency. For primers whose amplification efficiencies were similar to that of the endogenous control (slope of the graph $\Delta \mathrm{Ct}$ vs. log dilutions $\leq 0.1$ ) the $\Delta \mathrm{Ct}$ method was used, where the equation $2^{-\Delta \Delta \mathrm{Ct}}$ determines the amount of a target relative to a calibrator sample. If amplification efficiencies were not similar, the standard curve method was used for relative quantitation of target gene expression. Further information on both of these methods can be found on User Bulletin3 on the ABI website.

\section{Immunoblotting}

Freshly treated cells were lysed in NP40 lysis buffer (50 mM HEPES pH 7.4, $150 \mathrm{mM} \mathrm{NaCl}, 1 \%$ NP40, 1 mM EDTA) with protease and phosphatase inhibitors: pepstatin A $(1 \mu \mathrm{g} / \mathrm{mL})$, leupeptin $(1 \mu \mathrm{g} / \mathrm{mL})$, AEBSF $(100 \mu \mathrm{g} / \mathrm{mL})$, aprotinin $(17 \mu \mathrm{g} / \mathrm{mL})$, sodium orthovanadate $(2 \mathrm{mM})$, okadaic acid $(1 \mu \mathrm{M})$, fenvalerate $(5 \mu \mathrm{M})$ and $\mathrm{bpV}(5 \mu \mathrm{M})$. Protein concentration was determined using a Bradford assay and equal amounts of protein used for SDS-PAGE and immunoblotting with commercially-available antibodies (Additional file 1). Antibodies were detected with appropriate HRP-conjugated secondary antibodies and detected by enhanced chemiluminescence (Perkin Elmer). All membranes were reprobed for beta-actin and densitometry performed on all bands using a GS-800 Calibrated Densitometer and QuantityOne software (both BioRad) with local background subtraction. Intensities for each band were then normalized to the actin band in that lane. Normalized values were averaged from 3-5 independent blots and plotted using the standard deviation as the error.

\section{Small interfering RNA (siRNA) reverse transfection}

HB4a, C3.6, or SKBR3 cells were withdrawn from antibiotics for a minimum of 2 hrs and subsequently transfected with siRNA pools targeting ErbB2, IGFBP3 or non-targeting scrambled control siRNA (Dharmacon RNA Technologies); the ON-TARGET plus non-targeting control siRNA pool was used in invasion, proliferation and stimulation assays, whilst the \#2 ON-TARGET plus non-targeting control siRNA was used in anchorage-independence growth assays. Reverse transfection was performed in 6-well plates according to the manufacturer's instructions using Lipofectamine ${ }^{\mathrm{Tm}}$ RNAi Max (Invitrogen) and diluting the siRNA with Opti-Mem ${ }^{\circ}$ reduced serum medium (Invitrogen). A final concentration of $50 \mathrm{nM}$ of siRNA was typically used to transfect $2.5 \times 10^{5}$ cells per well (or $1.5 \times 10^{5}$ for silGFBP3 knockdown in SKBR3) which were then maintained in their normal growth medium. Cells were typically harvested $96 \mathrm{hrs}$ post-transfection in $200 \mu \mathrm{L}$ of NP40 lysis buffer and expression knockdown confirmed by western blotting as described.

\section{Invasion assays}

Transfected SKBR3 cells were subjected to a matrigelbased invasion assay utilizing a 24-well BD Biocoat ${ }^{\text {TM }}$ Tumour Invasion Assay System (BD Biosciences) according to the manufacturer's instructions. At 96 hours post-transfection, cells were harvested, counted and plated at $1 \times 10^{5}$ cells/chamber in DMEM/F-12 medium supplemented with $0.1 \%$ (v/v) FCS, $100 \mu \mathrm{g} / \mathrm{mL}$ streptomycin and $100 \mathrm{IU} / \mathrm{mL}$ penicillin. The lower chamber contained a chemo-attractant of DMEM/F-12 medium supplemented with $10 \%(\mathrm{v} / \mathrm{v})$ FCS. Invaded cells on the underside of the membrane were fixed and stained after 72 hours in a 99\% methanol, 1\% crystal violet solution and counted under a bright field microscope with the Image J software. Experiments were performed in triplicate for each siRNA and cells in 5 fields per membrane were counted.

\section{Proliferation assays}

Transfected cells were harvested after $96 \mathrm{hrs}$, counted and plated at $3 \times 10^{3}(\mathrm{SKBR} 3)$ and $5 \times 10^{3}$ cells/well (HMLEC) into 96-well plates in DMEM/F-12 medium supplemented with $10 \%(\mathrm{v} / \mathrm{v}) \mathrm{FCS}, 100 \mu \mathrm{g} / \mathrm{mL}$ streptomycin and $100 \mathrm{IU} / \mathrm{mL}$ penicillin with 5 replicates per condition. The number of viable cells was ascertained utilizing a MTT (3-(4, 5-dimehylthiazol-2-yl)-2-5dyphennyltetrazolium bromide) assay after $48 \mathrm{hrs}$. For this, cells were incubated with $50 \mu \mathrm{L} /$ well of $1 \mathrm{mg} / \mathrm{mL}$ MTT which is converted to purple formazan crystals by 
viable cells. After $5 \mathrm{hr}$ crystals were solubilised in $100 \mu \mathrm{L}$ of DMSO, shaken at room temperature for $10 \mathrm{~min}$ and the absorbance measured at $540 \mathrm{~nm}$ using a microtitre plate spectrophotometer.

\section{Anchorage-independence growth assays}

Transfected SKBR3 cells were harvested after 96 hrs, counted and re-suspended in DMEM/F-12 medium supplemented with $10 \%(\mathrm{v} / \mathrm{v})$ FCS, $100 \mu \mathrm{g} / \mathrm{mL}$ streptomycin, $100 \mathrm{IU} / \mathrm{mL}$ penicillin and $10 \%(\mathrm{v} / \mathrm{v})$ of a $10 \mathrm{mg} / \mathrm{mL}$ bacto-peptone solution which contained $3.3 \%(\mathrm{v} / \mathrm{v})$ noble agar (both Sigma). Cells were plated at $2 \times 10^{4}$ cells/well into 6-well plates containing DMEM/F-12 medium supplemented with $10 \%(\mathrm{v} / \mathrm{v})$ FCS, $100 \mu \mathrm{g} / \mathrm{mL}$ streptomycin, $100 \mathrm{IU} / \mathrm{mL}$ penicillin and $10 \%(\mathrm{v} / \mathrm{v})$ of a $10 \mathrm{mg} / \mathrm{mL}$ bacto-peptone solution with $6 \%(\mathrm{v} / \mathrm{v})$ noble agar. Colonies were fixed and stained after 14 days with $1 \mathrm{mg} / \mathrm{mL}$ p-iodotertazolium violet (Sigma) prepared in absolute methanol and counted using the Image J software. Experiments were performed in triplicate and 5 fields were counted per plate.

\section{Results}

\section{ErbB2 and growth factor CDNA microarray analysis}

Our aim was to identify time-dependent and growth factor-specific changes in gene expression associated with long-term EGF and HRG $\beta 1$ (hereafter HRG) stimulation of a model HMLEC system. The concentrations of growth factor used $(1 \mathrm{nM})$ were selected based on minimum concentrations required for maximal activation of the ERK1/2 and Akt pathways as measured by western blotting with phospho-specific antibodies (data not shown). We also wanted to assess how such gene expression changes are affected by ErbB2 overexpression in order to understand how ErbB2 contributes to signalling events associated with breast epithelial cell transformation. Microarray experiments were thus carried out using a previously described ErbB2-overexpressing HMLEC system [31,32]. Serum-starved HB4a parental cells and ErbB2-overexpressing C3.6 cells were stimulated with EGF or HRG for $4 \mathrm{~h}, 18 \mathrm{~h}$ and $24 \mathrm{~h}$ or left unstimulated $(0 \mathrm{~h})$ prior to microarray analysis of mRNA levels of 9,932 probes, representing $\sim 6,000$ genes. These timepoints were chosen to assess the medium-term effects on gene expression that occur within the doubling time of the cells.

Four replicates of each sample were co-hybridized to chips with a common RNA reference allowing direct comparison of gene expression across all experimental conditions: time, GF and cell line. The excel add-in software SAM (Significance Analysis of Microarray) [34] was used to perform pair-wise comparisons of all conditions, identifying 1,995 significant changes, representing 775 genes whose expressions were either responsive to EGF and/or
HRG, genes differentially regulated by ErbB2 overexpression, or both. Of these, 145 genes occurred more than once where probes on the arrays corresponded to different sequences of the same gene. In general, these duplicates and triplicates displayed similar patterns of expression, increasing confidence in the observed changes. Full gene lists grouped by responsiveness are available in Additional file 2. Fig $1 \mathrm{~A}$ and $1 \mathrm{~B}$ show the number of genes and their overlapping responses. There were a greater number of genes up- or down-regulated by HRG in the C3.6 cells than EGF, whilst EGF was generally more potent at inducing expression in the HB4a parental cells. Timedependent changes in the response to each GF were also apparent between cell lines, indicating that ErbB2 overexpression alters the kinetics of downstream signalling events. Functional classification of the 775 genes revealed a wide range of gene families, with kinases, $\mathrm{CD}$ antigens and receptors featuring prominently (Fig. 1C). There were surprisingly few known EGF-responsive genes, although this may reflect the timepoints employed and/or insufficient database annotation. Fifty-two genes had no functional annotation and represent novel genes that warrant further study.

Ratios of normalized values were next used to show relative gene expression in two ways: (i) the EGF or HRG ratio $\left(\mathrm{T}^{*} / \mathrm{T} 0\right)$ representing gene expression at each timepoint relative to untreated control for both cell lines, and (ii) the ErbB2 ratio (C3.6/HB4a) representing relative gene expression in C3.6 versus HB4a cells at each timepoint. Ratios were used for unsupervised hierarchical clustering of all 775 genes (Fig. 2). Although no striking functional clusters were apparent, there were several interesting features. One group of genes displayed altered expression correlating with ErbB2, but displayed similar levels of up- or down-regulation in response to both growth factors (light green and pink bands, Fig. 2). A second group of genes was down-regulated by ErbB2, but potently up-regulated by EGF treatment (light blue band). A third large group of genes displayed transient induction (up at $4 \mathrm{~h}$ only) in all treatments, but less so with HRG in the HB4a cells (red band). A fourth group of genes were down-regulated in response to both GFs (dark green band). Finally, two features clustered away from the other 773 genes (top of cluster in Fig. 2) and represented IGFBP3, a putative regulator of insulin-like growth factor (IGF)-dependent and independent proliferation, differentiation and survival. IGFBP3 expression was strongly suppressed by ErbB2 overexpression and down-regulated by both GFs (Fig. 3A \&3B).

\section{Growth factor-induced genes augmented by ErbB2 overexpression}

Genes transiently induced by both GFs and whose expressions were induced more strongly in the 
A

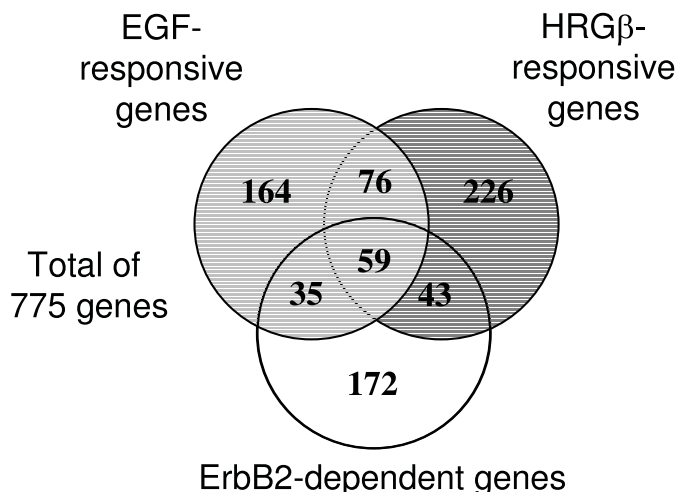

$\mathrm{B}$
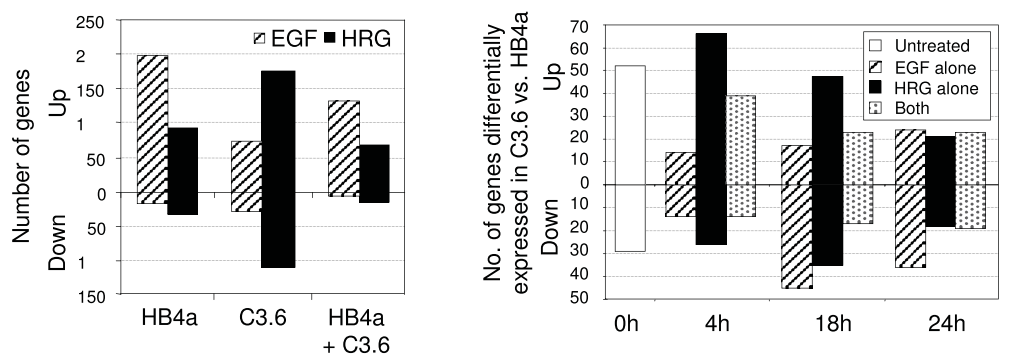

C

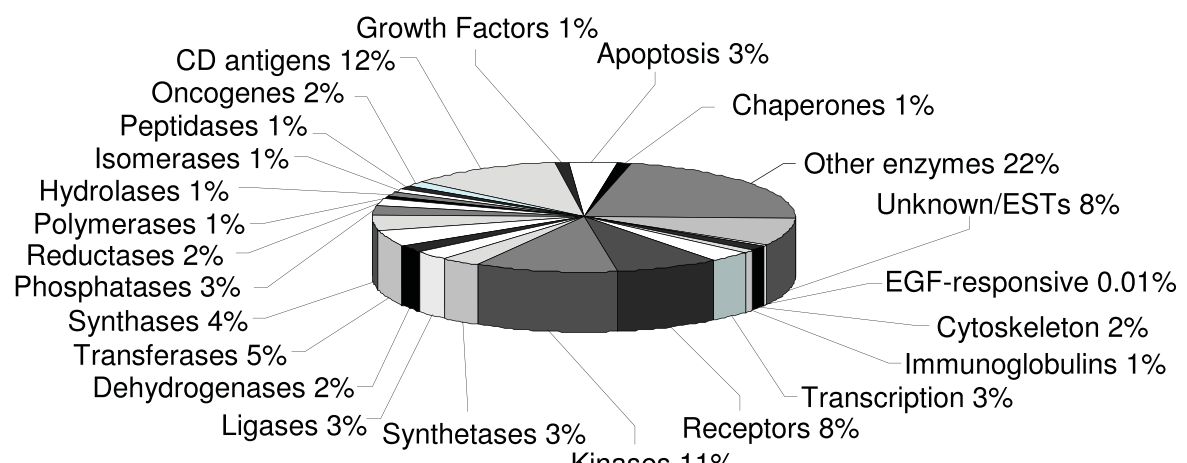

Kinases $11 \%$

Figure 1 Numbers and functions of differentially expressed genes. A. Venn diagram showing the distribution of the 775 genes found to be significantly differentially expressed and their co-regulation by EGF, HRG and ErbB2. B. Distribution of up- or down-regulated genes by cell line and growth factor (left) and in C3.6 vs. HB4a over time (right). C. Distribution of functional classes of differentially regulated genes based on GO terms for molecular function.

ErbB2-overexpressing cells are of particular interest in ErbB2-dependent cell transformation. These genes included transcription factors MYC (Fig. 3C), ZFP36L1, ZFP36L2, FOSL1 and ATF4/CREB2, growth factors VEGF and PDGFB and signalling kinases LYN, MAP2K1/MEK1 and MAP2K3/MEK3 (Fig. 3D). Also in this group, were the MYC-induced glycoprotein
EMP1, which showed a similar pattern of expression to MYC (Fig. 3E), and BCAR3 (Fig. 3F), a novel SH2 and GEF domain-containing gene. A number of genes associated with cytoskeletal organization and adhesion were also induced more robustly in the ErbB2 overexpressing cells, particularly in response to HRG. These genes included zyxin (ZYX) (Fig. 3G), transgelin 


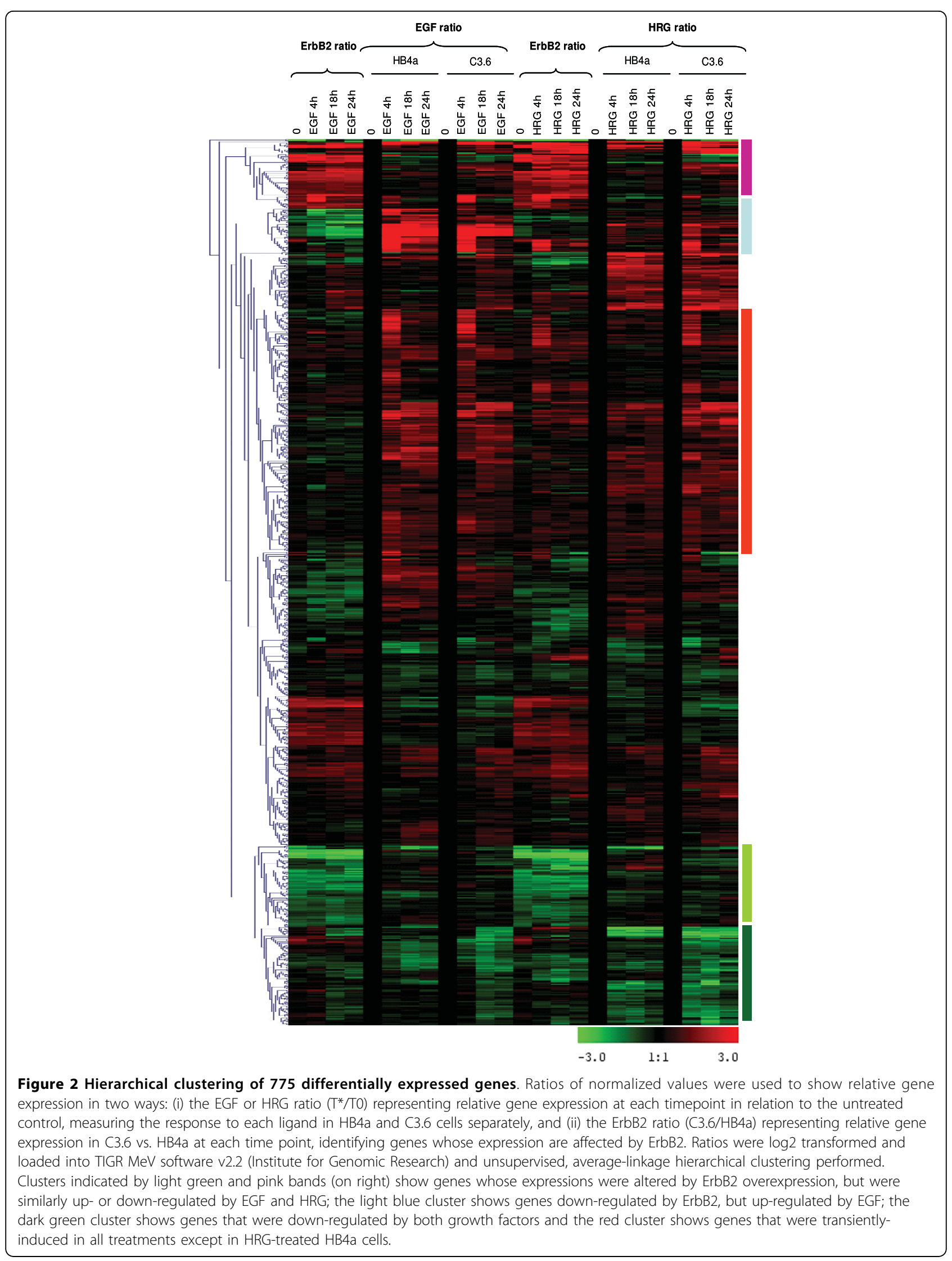




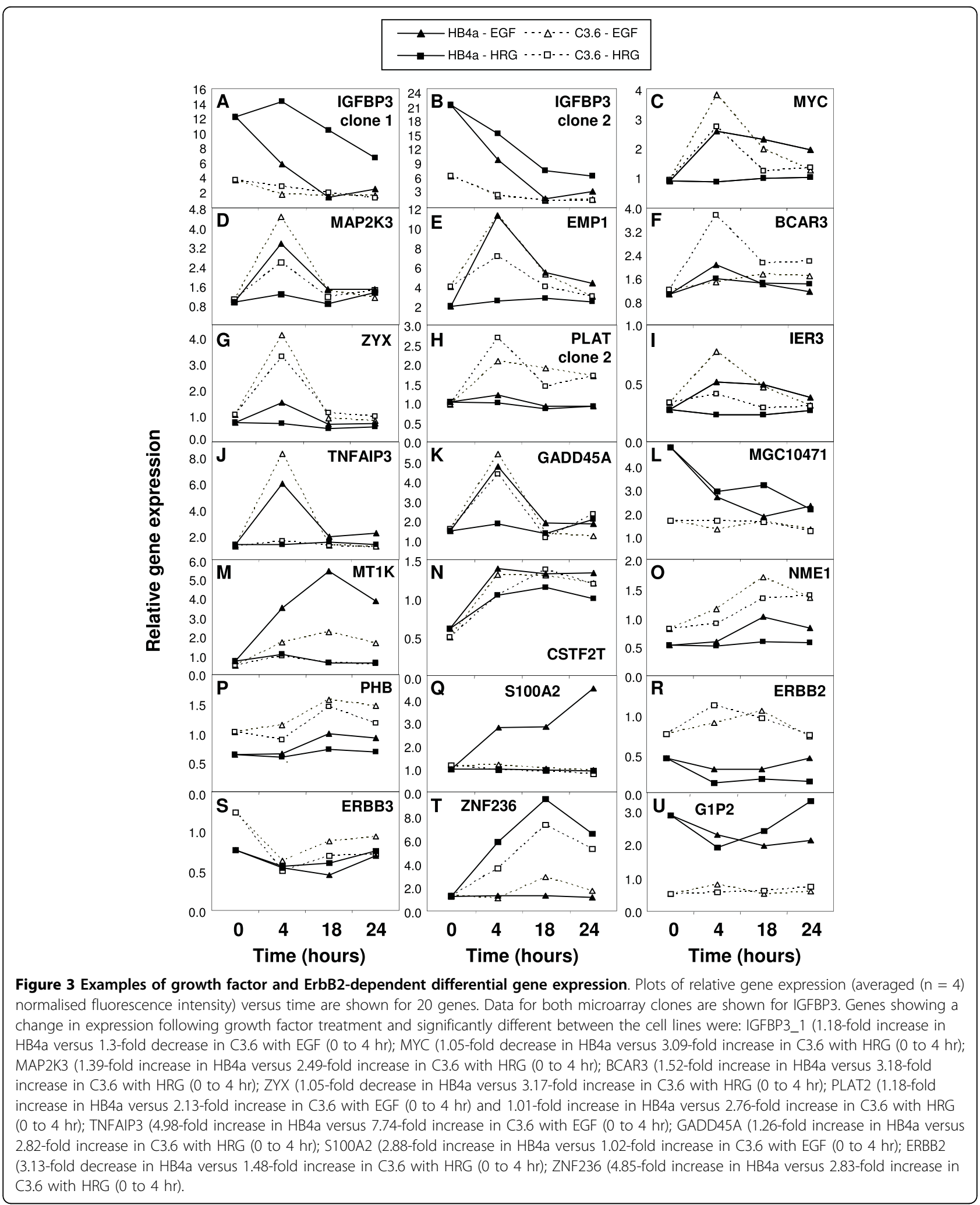


(TAGLN), thrombospondin 1 (THBS1), vinculin (VCL), calponin 3 (CNN3), villin 2/ezrin (VIL2), myosin 1E (MYO1E), stathmin 3 (STMN3), Crk-associated substrate-related protein (NEDD9/CASL), ladinin 1 (LAD1) and integrin $\alpha 2$ and $\alpha 3$ (ITGA2 and ITGA3). Members of the plasminogen activator system; tissuetype plasminogen activator (PLAT) (Fig 3H), urokinase-type plasminogen activator receptor (PLAUR), plasminogen activator inhibitor 1 (PAI1/SERPINE1) and the plasminogen and PLAT co-receptor annexin A2 (ANXA2), were also present in this group. The anti-apoptotic genes IER3 and TNFAIP3 (Fig. 3I \&3J) were also more highly induced in the ErbB2-overexpressing cells, as were the poorly characterized genes S100P, CSRP1, HPCAL1 and SMAP, identifying them as potential effectors of ErbB signalling. Finally, and perhaps surprisingly, the genotoxic stress-induced growth arrest gene GADD45A (Fig. 3K) and the MAPK phosphatases DUSP1/MKP1 and DUSP5 were both induced by growth factor treatment.

\section{Growth factor-induced gene expression changes}

In order to analyze EGF and HRG-specific changes in gene expression regardless of ErbB2 level, three gene lists were generated according to the Venn diagram in Fig. 1A: (i) EGF-responsive (199 genes); (ii) HRGresponsive (269 genes); and (iii) genes responsive to both (135 genes). Genes in each list were grouped by $k$-means clustering into 4 clusters displaying similar patterns of expression. Fig 4A shows the average expression patterns for genes regulated by both GFs and reveals that a considerable number were less potently induced (or not induced) by HRG in the HB4a cells (Fig. 4A; clusters 2 \& 3). Of the 13 genes in cluster 2 (Figs. 4A \& Additional file 3), six were clones of the metallothionein (MT) family of cysteine-rich, heavy metal-binding proteins and were potently induced by EGF (Fig. 3M). This cluster also included cytoskeletal components keratin 6 (KRT6D/B), transgelin (TAGLN) and coactosin-like 1 (COTL1) and a novel polyadenylation protein variant tauCstF-64 (CSTF2T) (Fig. 3N). Cluster 3 genes (Fig. $4 B$ ) included SFN, a negative regulator of $\mathrm{G} 2 / \mathrm{M}$ progression and the adhesion-related genes villin 2/ezrin (VIL2), syndecan 4 (SDC4), integrin- $\alpha 3$ (ITGA3), integrin- $\beta 1$ (ITGB1) laminin- $\alpha 3$ (LAMA3), paxillin (PXN) and vinculin (VCL). Clusters 1 and 4 showed a more similar pattern of regulation in the two cell lines and their regulation is therefore less likely to be dependent upon ErbB2 signalling. Cluster 1 genes were down-regulated in response to GF treatment and included genes involved in the response to oxidative stress (PRDX5, GSTP1, MGST3, TXNIP and ALDH1A3). Notably, a gene of unknown function (MGC10471/CCDC130) was potently repressed by both GFs in HB4a cells, and was constitutively down-regulated in C3.6 cells, similar to IGFBP3 (Fig. 3L). Such novel genes are of particular interest since they may be components of as yet uncharacterized GF-dependent pathways. wfdc2 Cluster 4 genes were moderately up-regulated by EGF and HRG, and included genes with reported roles in proliferation and tumour suppression, such as MYBL2, FOXM1, NME1 (Fig. 3O) and PHB (Fig. 3P).

Genes induced specifically by EGF included C14orf31, CDH3, CAV1, ACTB, CTNNAL1, PTPN1, S100A11, TIMP1, TMSB10 and TXN, linking them to signalling through EGFR-containing dimers. A group of EGF-specific genes were induced almost exclusively in HB4a cells and included the EGFR ligand AREG (Fig. 5), the cysteine protease cathepsin $\mathrm{C}$ (CTSC) (Fig. 5), the $\mathrm{Ca}^{2+}$-binding protein S100A2 (Fig. 3Q) and hypoxia inducible factor 2A (HIF2A), a transcription factor involved in the induction of oxygen-regulated genes such as VEGF (see above). There were no genes exclusively down-regulated by EGF, although IGFBP3 and the transmembrane glycoprotein MUC1 showed a stronger response to EGF than HRG. There were significantly more genes responsive to HRG, and although the inductions were generally weaker, their expressions were often sustained. ERBB2 and ERBB3 (Fig. 3R \&3S) were among the genes down-regulated by HRG, suggesting a feedback mechanism through regulated transcription. Noticeably, ERBB2 and ERBB3 gene expression was higher in the C3.6 cells, in accordance with previously established protein levels [32]. Genes potently induced by HRG compared to EGF included metabolic enzymes, transcription factors (MADH4 and STAT1), the cell cycle inhibitor CDKN1A/p21CIP, the protease inhibitor SLPI, fibronectin 1 (FN1), keratin 15 (KRT15) and the poorly characterized NUP214 and zinc finger-containing gene (ZNF236) (Fig. 3T). Figures of $K$-means clusters of genes regulated by either EGF or HRG can be found in Additional files 4 and 5.

\section{ErbB2-dependent gene expression}

A group of genes displayed differential expression between the cell lines, but were either unresponsive to GF treatment or responded similarly in the two cell lines (Table 1). These included several metabolic enzymes that were more highly expressed in the C3.6 cells, and eight known interferon-stimulated genes (ISGs) that displayed reduced expression. The ISGs included the ubiquitin-like modifier G1P2/ISG15, which was the most suppressed gene in the dataset (Fig. 3U), and ISGF3G/p48/IRF9, the third component of a STAT1and STAT2-containing transcription factor complex that controls interferon (IFN)-mediated gene expression. Finally, several genes of poorly-defined or unknown function (AGR2, PSCA, PKM2, NME1, CPNE3, LCP1, S100P, SERF2 and LOC402057) were constitutively 
A

EGF \& HRG $k$-means clustering

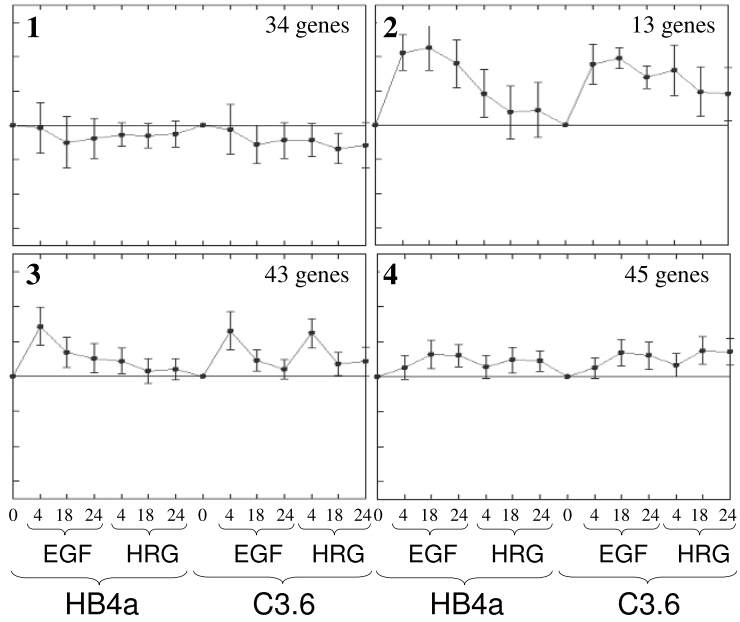

B

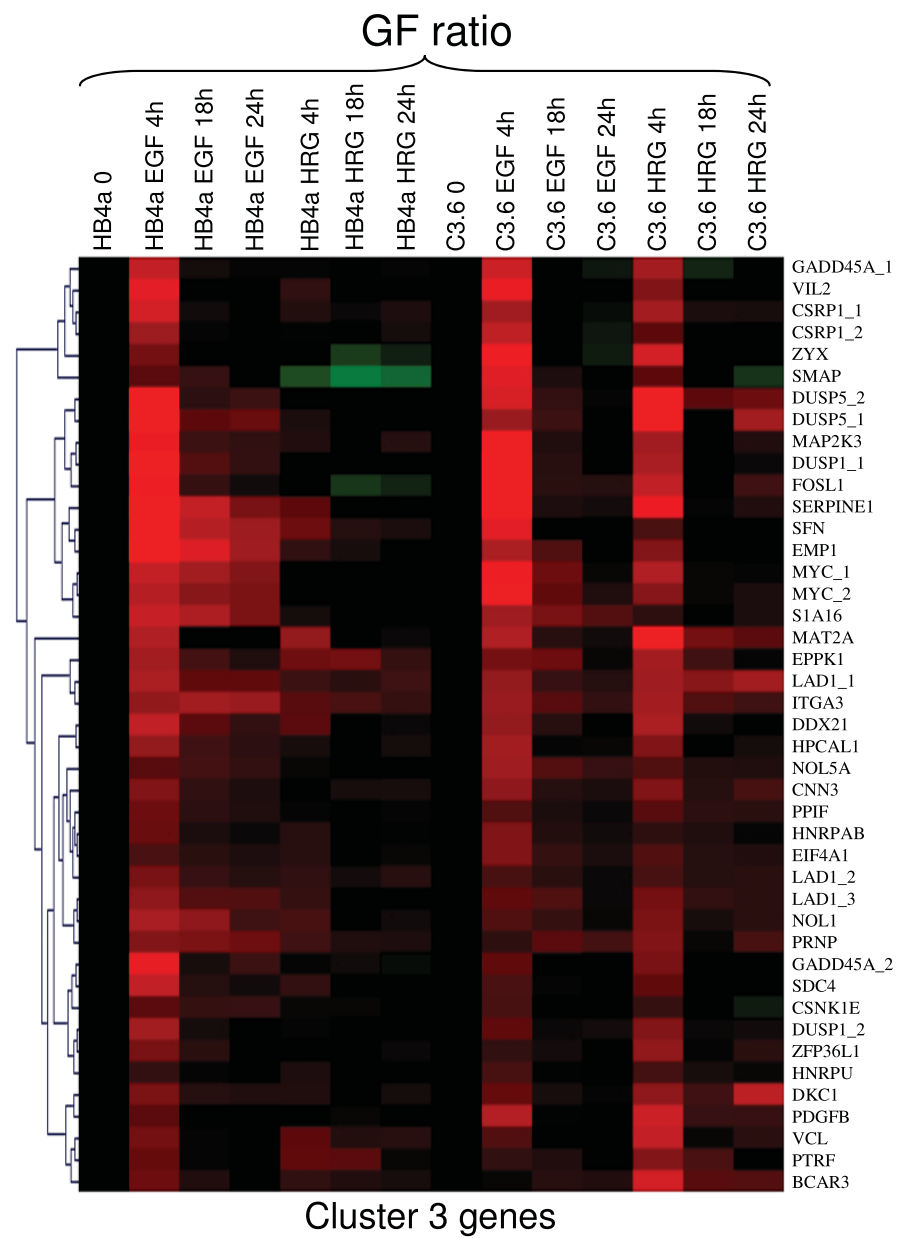

Figure $4 \mathrm{~K}$-means clustering and hierarchical clustering of EGF and HRG-responsive genes. A. For $k$-means clustering in TIGR MeV software v2.2 (Institute for Genomic Research), growth factor-responsive genes from SAM were grouped separately and sub-divided into a userdefined number $(k=4)$ of groups. Plots show the four groups as average expression patterns for genes regulated by both growth factors. B. Group 3 genes which were transiently induced by both growth factors except by HRG in HB4a cells were subjected to hierarchical clustering as above. 


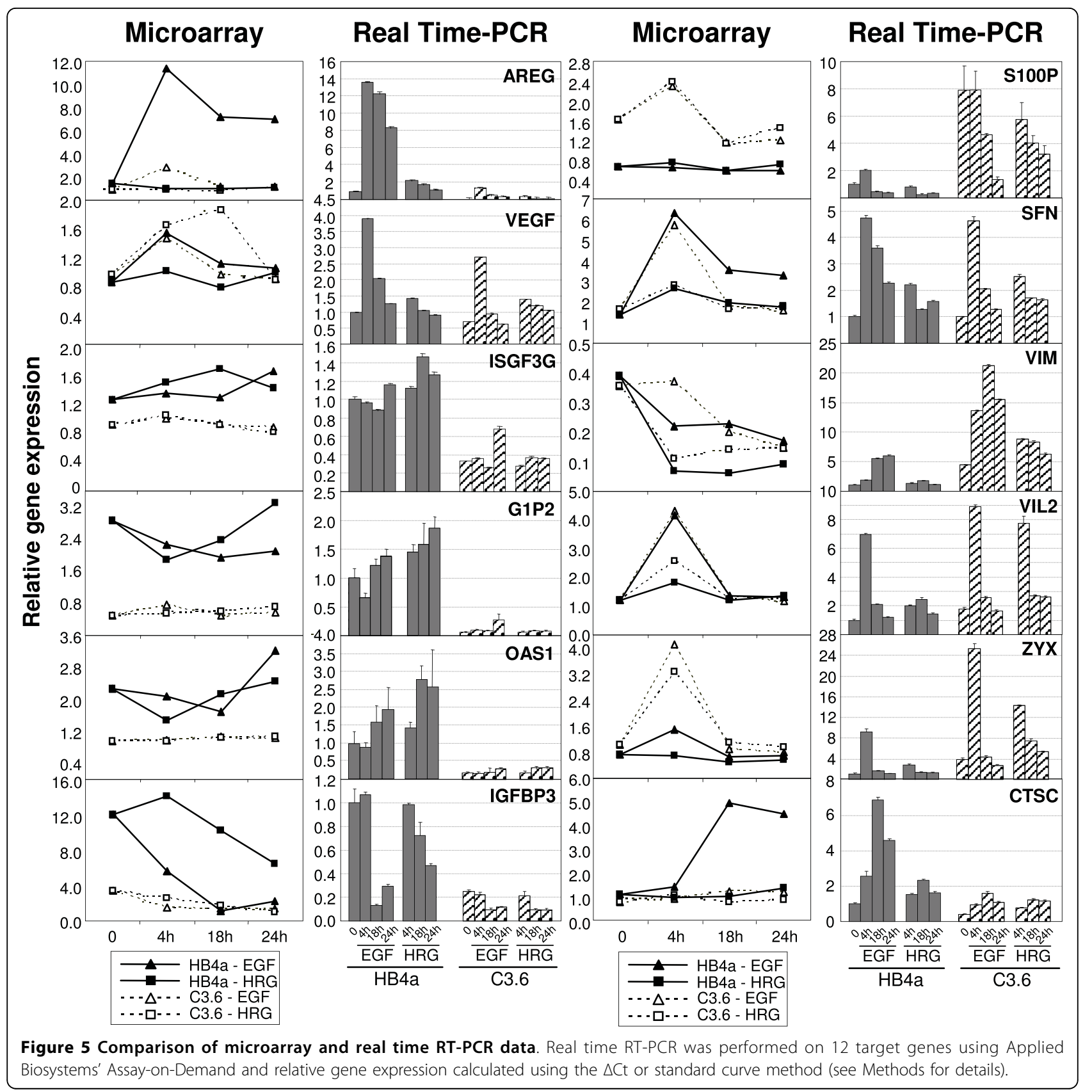

up-regulated in the C3.6 cells (Table 1) and may represent novel markers of ErbB2-dependent transformation.

\section{Validation of gene expression changes}

A set of genes of interest from the microarray analysis were chosen for validation using semi-quantitative realtime PCR and/or immunoblotting. In general, there was good agreement between the microarray and RT-PCR datasets for genes examined, although fold-changes were generally higher and data more reproducible for the RTPCR analyses (Fig. 5). Thus, EGF and/or HRG treatment induced AREG, VEGF, SFN, VIL2, ZYX and CTSC expression, with a more potent induction of VIL2 and ZYX in C3.6 cells, in agreement with the microarray data. Also in agreement, IGFBP3 and three ISGs (ISGF3G, G1P2 and OAS1) were all expressed at lower levels in C3.6 cells with IGFBP3 potently down-regulated by both GFs in the HB4a cells, whilst S100P was overexpressed in the C3.6 cells. One exception was vimentin (VIM), where RT-PCR showed increased expression in C3.6 cells with potent induction by EGF and $H R G$, rather than the down-regulation suggested 
Table 1 Genes displaying differential expression between HB4a and C3.6 cell lines

\begin{tabular}{|c|c|c|c|}
\hline Symbol & Ensembl Number and Description & GO Biological Process & $\begin{array}{l}\text { Fold Change } \\
\text { (at T0) }\end{array}$ \\
\hline${ }^{*} \mathrm{ALDH} 1 \mathrm{~A} 3$ & ENSG00000184254:ALDEHYDE DEHYDROGENASE 6 & GO:0006629:lipid metabolism & 5.45 \\
\hline KRT15 & ENSG00000171346:KERATIN, TYPE I CYTOSKELETAL 15 & GO:0008544:epidermal differentiation & 4.66 \\
\hline${ }^{*} \mathrm{AGR} 2$ & ENSG00000106541:ANTERIOR GRADIENT 2 & Unknown & 4.00 \\
\hline NCKAP1 & ENSG00000061676:NCK-ASSOCIATED PROTEIN 1 (NAP 1) & GO:0006915:apoptosis & 3.87 \\
\hline COX6C & ENSG00000164919:CYTOCHROME C OXIDASE POLYPEPTIDE VIC & GO:0006091:energy pathways & 3.37 \\
\hline PSCA & ENSG00000167653:PROSTATE STEM CELL ANTIGEN PRECURSOR & Unknown & 2.94 \\
\hline *KRT13 & ENSG00000171401:KERATIN, TYPE I CYTOSKELETAL 13 & GO:0008544:epidermal differentiation & 2.69 \\
\hline YWHAZ & ENSG00000164924:14-3-3 PROTEIN ZETA/DELTA & GO:0007165:signal transduction & 2.47 \\
\hline *S100P & ENSG00000163993:S-100P PROTEIN & Unknown & 2.45 \\
\hline *PKM2 & ENSG00000067225:PYRUVATE KINASE, MUSCLE & GO:0006096: glycolysis & 2.41 \\
\hline TRAM1 & ENSG00000067167:TRAM PROTEIN & GO:0006605:protein targeting & 2.38 \\
\hline ATP5L & ENSG00000167283:ATP SYNTHASE G CHAIN, MITOCHONDRIAL & $\begin{array}{l}\text { GO:0015992:proton transport; GO:0006754:ATP } \\
\text { biosynthesis }\end{array}$ & 2.26 \\
\hline SLC7A7 & ENSG00000155465:Y+L AMINO ACID TRANSPORTER 1 & GO:0006832:small molecule transport & 2.25 \\
\hline SSBP1 & ENSG00000106028:SINGLE-STRANDED DNA-BINDING PROTEIN & GO:0006260:DNA replication & 2.25 \\
\hline SERF2 & ENSG00000140264:SMALL EDRK-RICH FACTOR 2 & Unknown & 2.21 \\
\hline NEDD9 & ENSG00000111859:ENHANCER OF FILAMENTATION 1 (HEF1) & $\begin{array}{l}\text { GO:0007155:cell adhesion; GO:0000074:regulation of } \\
\text { cell cycle }\end{array}$ & 2.18 \\
\hline SCAMP2 & $\begin{array}{l}\text { ENSG00000140497:SECRETORY CARRIER-ASSOCIATED MEMBRANE } \\
\text { PROTEIN } 2\end{array}$ & GO:0006886:intracellular protein transport & 2.12 \\
\hline EMP1 & ENSG00000134531:EPITHELIAL MEMBRANE PROTEIN-1 & GO:0007048:oncogenesis;GO:0008283:cell proliferation & 2.10 \\
\hline *LCP1 & ENSG00000136167:L-PLASTIN & Unknown & 2.09 \\
\hline MGST1 & $\begin{array}{l}\text { ENSG00000008394:MICROSOMAL GLUTATHIONE S-TRANSFERASE } \\
1\end{array}$ & GO:0032496: response to lipopolysaccharide & 2.06 \\
\hline DUT & $\begin{array}{l}\text { ENSG00000128951:DEOXYURIDINE 5'-TRIPHOSPHATE } \\
\text { NUCLEOTIDOHYDROLASE }\end{array}$ & GO:0006260:DNA replication & 2.05 \\
\hline DDX5 & ENSG00000108654:PROBABLE RNA-DEPENDENT HELICASE P68 & GO:0016049:cell growth & 2.00 \\
\hline SRP14 & $\begin{array}{l}\text { ENSG00000140319:SIGNAL RECOGNITION PARTICLE } 14 \text { KDA } \\
\text { PROTEIN }\end{array}$ & GO:0006605:protein targeting & 1.98 \\
\hline *ANXA2 & ENSG00000183059:ANNEXIN II (LIPOCORTIN II) & GO:0001501:skeletal development & 1.95 \\
\hline PBP & $\begin{array}{l}\text { ENSG00000089220:PHOSPHATIDYLETHANOLAMINE-BINDING } \\
\text { PROTEIN }\end{array}$ & Unknown & 1.80 \\
\hline ATP5G3 & ENSG00000154518:ATP SYNTHASE LIPID-BINDING PROTEIN & $\begin{array}{l}\text { GO:0006091:energy pathways; GO:0015992:proton } \\
\text { transport }\end{array}$ & 1.78 \\
\hline SRI & ENSG00000075142:SORCIN (22 KDA PROTEIN) & GO:0007517:muscle development & 1.77 \\
\hline RPL17 & ENSG00000141618:60S RIBOSOMAL PROTEIN L17 & GO:0006412:protein biosynthesis & 1.71 \\
\hline *ERBB2 & $\begin{array}{l}\text { ENSG00000141736:V-ERBB2 ERYTHROBLASTIC LEUKEMIA VIRAL } \\
\text { ONCOGENE HOMOLOG } 2\end{array}$ & $\begin{array}{l}\text { GO:0007169:transmembrane receptor protein tyrosine } \\
\text { kinase signaling }\end{array}$ & 1.67 \\
\hline${ }^{*} \mathrm{AKR} 1 \mathrm{~B} 1$ & ENSG00000085662:ALDOSE REDUCTASE & GO:0005975:carbohydrate metabolism & 1.66 \\
\hline ATP6V1F & ENSG00000128524:VACUOLAR ATP SYNTHASE SUBUNIT F & $\begin{array}{l}\text { GO:0015992:proton transport; GO:0006754:ATP } \\
\text { biosynthesis }\end{array}$ & 1.66 \\
\hline ATP5G1 & ENSG00000159199:ATP SYNTHASE LIPID-BINDING PROTEIN & GO:0015992:proton transport & 1.64 \\
\hline UBN1 & ENSG00000118900:UBINUCLEIN 1 & GO:0016568:chromatin modification & 1.63 \\
\hline *ERBB3 & $\begin{array}{l}\text { ENSG00000065361:V-ERBB2 ERYTHROBLASTIC LEUKEMIA VIRAL } \\
\text { ONCOGENE HOMOLOG } 3\end{array}$ & $\begin{array}{l}\text { GO:0007169:transmembrane receptor protein tyrosine } \\
\text { kinase signaling }\end{array}$ & 1.62 \\
\hline FTH1 & ENSG00000167996:FERRITIN HEAVY CHAIN & $\begin{array}{l}\text { GO:0008283:cell proliferation; GO:0006826:iron } \\
\text { transport }\end{array}$ & 1.62 \\
\hline ST14 & ENSG00000149418:SUPPRESSOR OF TUMORIGENICITY 14 & GO:0006508:proteolysis and peptidolysis & 1.62 \\
\hline *PHB & ENSG00000167085:PROHIBITIN & GO:0008151:cell growth and/or maintenance & 1.59 \\
\hline CLTC & ENSG00000141367:CLATHRIN HEAVY CHAIN 1 & GO:0006886:intracellular protein transport & 1.51 \\
\hline APLP2 & ENSG00000084234:AMYLOID-LIKE PROTEIN 2 PRECURSOR & $\begin{array}{l}\text { GO:0007186:G-protein coupled receptor protein } \\
\text { signaling pathway }\end{array}$ & 1.48 \\
\hline
\end{tabular}


Table 1 Genes displaying differential expression between HB4a and C3.6 cell lines (Continued)

\begin{tabular}{|c|c|c|c|}
\hline HSBP1 & ENSG00000166530:HEAT SHOCK FACTOR BINDING PROTEIN 1 & $\begin{array}{l}\text { GO:0000122:negative regulation of transcription from } \\
\text { Pol II promoter }\end{array}$ & 1.48 \\
\hline *NME1 & ENSG00000239672:NON-METASTATIC CELLS 1 & $\begin{array}{l}\text { GO:0045786:negative regulation of cell cycle; } \\
\text { GO:0009142: NTP biosynthesis }\end{array}$ & 1.47 \\
\hline *CPNE3 & ENSG00000085719:COPINE III & Unknown & 1.46 \\
\hline *ISGF3G † & ENSG00000213928:INTEREFERON REGULATORY FACTOR 9 & $\begin{array}{l}\text { GO:0006355:regulation of transcription; GO:0006955: } \\
\text { immune response }\end{array}$ & 0.73 \\
\hline *USP14 † & ENSG00000101557:UBIQUITIN SPECIFIC PEPTIDASE 14 & GO:0006511:ubiquitin-dependent protein catabolism & 0.71 \\
\hline SSR4 & ENSG00000180879:SIGNAL SEQUENCE RECEPTOR DELTA & GO:0006886:intracellular protein transport & 0.69 \\
\hline RAB7 & ENSG00000075785:RAS-RELATED PROTEIN RAB-7 & $\begin{array}{l}\text { GO:0007264:small GTPase mediated signal } \\
\text { transduction; GO:0006897:endocytosis }\end{array}$ & 0.69 \\
\hline SHMT2 & ENSG00000182199:SERINE HYDROXYMETHYLTRANSFERASE & GO:0006520:amino acid metabolism & 0.68 \\
\hline NGFRAP1 & $\begin{array}{l}\text { ENSG00000166681:NERVE GROWTH FACTOR RECEPTOR } \\
\text { ASSOCIATED PROTEIN } 1\end{array}$ & GO:0007275:development; GO:0006915:apoptosis & 0.66 \\
\hline HAT1 & ENSG00000128708:HISTONE ACETYLTRANSFERASE 1 & $\begin{array}{l}\text { GO:0006323:DNA packaging; GO:0006475: internal } \\
\text { protein amino acid acetylation }\end{array}$ & 0.65 \\
\hline PPP1CA & $\begin{array}{l}\text { ENSG00000172531:SERINE/THREONINE PROTEIN PHOSPHATASE } \\
\text { PP1-ALPHA } 1 \text { CATALYTIC SUBUNIT }\end{array}$ & GO:0006470:protein amino acid dephosphorylation & 0.65 \\
\hline UBL1 & ENSG00000116030:UBIQUITIN-LIKE PROTEIN SMT3C PRECURSOR & GO:0006281:DNA repair & 0.65 \\
\hline NPC2 & $\begin{array}{l}\text { ENSG000001 19655:EPIDIDYMAL SECRETORY PROTEIN E1 } \\
\text { PRECURSOR }\end{array}$ & GO:0000004:biological_process unknown & 0.65 \\
\hline GMPS & ENSG00000163655:GMP SYNTHASE & GO:0006164:purine nucleotide biosynthesis & 0.62 \\
\hline UBE2L6 † & ENSG00000156587:UBIQUITIN-CONJUGATING ENZYME E2L 6 & GO:0006512:ubiquitin cycle & 0.61 \\
\hline SF3B1 & NSG00000115524:SPLICING FACTOR 3B SUBUNIT 1 & GO:0006371:mRNA splicing & 0.58 \\
\hline ANXA1 & ENSG00000135046:ANNEXIN I & GO:0006928:cell motility;GO:0006629:lipid metabolism & 0.57 \\
\hline SDC1 & ENSG00000115884:SYNDICAN 1 & GO:0048627:myoblast development & 0.56 \\
\hline FXR1 & $\begin{array}{l}\text { ENSG00000114416:FRAGILE X MENTAL RETARDATION } \\
\text { SYNDROME RELATED PROTEIN } 1\end{array}$ & GO:0006915:apoptosis & 0.56 \\
\hline PLD3 & ENSG00000105223:SIMILAR TO VACCINIA VIRUS HINDIII K4L ORF & GO:0008152:metabolism & 0.53 \\
\hline RPN1 & $\begin{array}{l}\text { ENSG00000163902:DOLICHYL-DIPHOSPHOOLIGOSACCHARIDE- } \\
\text { PROTEIN GLYCOSYLTRANSFERASE }\end{array}$ & GO:0006464:protein modification & 0.51 \\
\hline *GSTP1 † & ENSG00000084207:GLUTATHIONE S-TRANSFERASE P & GO:0007417:central nervous system development & 0.51 \\
\hline$\overline{\mathrm{HDLBP}}$ & $\begin{array}{l}\text { ENSG00000115677:VIGILIN (HIGH DENSITY LIPOPROTEIN-BINDING } \\
\text { PROTEIN) }\end{array}$ & $\begin{array}{l}\text { GO:0006869:lipid transport; GO:0008203:cholesterol } \\
\text { metabolism }\end{array}$ & 0.5 \\
\hline TYMS & ENSG00000176890:THYMIDYLATE SYNTHASE & $\begin{array}{l}\text { GO:0006139:nucleobase, nucleoside, nucleotide and } \\
\text { nucleic acid metabolism }\end{array}$ & 0.44 \\
\hline WFDC2 & $\begin{array}{l}\text { ENSG00000101443:MAJOR EPIDIDYMIS-SPECIFIC PROTEIN E4 } \\
\text { PRECURSOR }\end{array}$ & GO:0006508:proteolysis and peptidolysis & 0.43 \\
\hline OAS1 † & ENSG00000089127:2',5'-OLIGOADENYLATE SYNTHETASE 1 & GO:0006955:immune response & 0.42 \\
\hline SERPINH1 & ENSG00000149257:COLLAGEN-BINDING PROTEIN 2 PRECURSOR & GO:0006950:response to stress & 0.39 \\
\hline CYBA & ENSG00000051523:CYTOCHROME B-245 ALPHA & $\begin{array}{l}\text { GO:0006118:electron transport; GO:0006801: } \\
\text { superoxide metabolism }\end{array}$ & 0.38 \\
\hline IFITM2 † & $\begin{array}{l}\text { ENSG00000185201:INTERFERON-INDUCED TRANSMEMBRANE } \\
\text { PROTEIN } 2\end{array}$ & GO:0006955:immune response & 0.34 \\
\hline IGFBP3 & $\begin{array}{l}\text { ENSG00000146674:INSULIN-LIKE GROWTH FACTOR BINDING } \\
\text { PROTEIN } 3 \text { PRECURSOR }\end{array}$ & $\begin{array}{l}\text { GO:0007165:signal transduction; GO:0001558:regulation } \\
\text { of cell growth }\end{array}$ & 0.31 \\
\hline ALDH1A1 & $\begin{array}{l}\text { ENSG00000165092:ALDEHYDE DEHYDROGENASE } 1 \text { FAMILY } \\
\text { MEMBER A1 }\end{array}$ & GO:0006081:aldehyde metabolism & 0.29 \\
\hline IFITM1 † & $\begin{array}{l}\text { ENSG00000185885:INTERFERON-INDUCED TRANSMEMBRANE } \\
\text { PROTEIN } 1\end{array}$ & $\begin{array}{l}\text { GO:0006955:immune response; GO:0008285:negative } \\
\text { regulation of cell proliferation }\end{array}$ & 0.25 \\
\hline *G1P2 † & ENSG00000182106:UBIQUITIN CROSS-REACTIVE PRECURSOR & $\begin{array}{l}\text { GO:0006955:immune response; GO:0007267:cell-cell } \\
\text { signaling }\end{array}$ & 0.17 \\
\hline
\end{tabular}

Gene symbol, name, function and fold-change in expression (C3.6 vs. HB4a) at T0 are shown for genes displaying differential expression between cell lines and which were relatively unresponsive to growth factor. *Indicates that the protein product of this gene displays the same directionality of differential expression (data from 2D-DIGE and immunoblotting experiments $([38,72,78]$ and Figure 6$)$ ). ${ }^{\dagger}$ Indicates the 8 down-regulated interferon-stimulated genes (ISGs). 
from the microarray. The reason for this discrepancy is unclear, although the RT-PCR data is likely to provide a more accurate measure of regulated expression. The protein expression of several targets was also examined to test if the observed mRNA changes were indeed translated at the protein level (Fig. 6 and Additional file 6). When comparing the effect of ErbB2 overexpression alone (i.e. between cell lines), there was reasonable concordance between relative protein and mRNA expression for MYC, CLDN4, ZYX, PHB, MAP2K1, NME1, AGR2, PKM2 and ANXA2, (all up-regulated) and IGFBP3, ISGF3G and G1P2 (all down-regulated) (Fig. 6B). However, GF-induced changes in protein level were only apparent for MYC, CLDN4, S100A6, ZYX and G1P2 (Fig. 6C). In particular, the robust repression of IGFBP3 mRNA by GF treatment was not observed at the protein level or the induction of DUSP1 and SFN.

\section{Altered expression of IGFBP3 may alter IGF1-dependent signalling}

Given the reduced expression of IGFBP3 in the C3.6 cells, IGFBP3's reported role in regulating IGF activity [35] and the reported aberrant regulation of the IGF system in breast cancer [36], we wanted to further examine if IGF1-induced signalling might be affected by ErbB2 overexpression in these cells. Cells were stimulated with IGF1 and proliferative and survival signalling assessed by immunoblotting with antibodies specific to the phosphorylated, activated forms of ERK1/2 and Akt. ERK2 phosphorylation was induced more rapidly in the C3.6 cells, though by $10 \mathrm{~min}$ the levels were similar in the two cell lines (Fig. 7A). Akt phosphorylation was also induced more rapidly, reaching a higher level and was sustained in the C3.6 cells. These effects were not due to altered expression of the IGF1 receptor (IGFR), which was equivalent in the two cell lines (Fig. 7B). These data show that early IGF1-dependent signalling events are enhanced in the ErbB2-overexpressing cells and may contribute to the enhanced proliferation we observed in the C3.6 cells in response to IGF1 treatment (Fig. 7C). We next assessed the involvement of ErbB2 in this phenomenon by targeting ErbB2 knockdown by transient reverse transfection with specific siRNAs and examined IGF1 signalling responses by immunoblotting (Fig. 8). Knockdown of ErbB2 expression in C3.6 cells $(>90 \%)$ resulted in a modest reduction of both basal and IGF1-induced ERK1/2 phosphorylation and substantial reduction of IGF1-induced Akt phosphorylation (Fig. 8A and $8 B$ ). There was no effect of ErbB2 knockdown or IGF1 treatment on intracellular IGFBP3 levels. Notably, partial knockdown of IGFBP3 $(\sim 60 \%)$ in the HB4a cells resulted in both enhanced basal ERK1/2 and Akt phosphorylation, with little effect on IGF1-stimulated levels (Fig. 8C). Knockdown of IGFBP3 in C3.6 had little effect on IGF1-dependent signalling, presumably as its levels are already very low in these cells (data not shown). Taken together, these data reveal a positive role for ErbB2 expression in enhancing IGF1-dependent signalling in these HMLECs, and also suggested that IGFBP3 acts a negative regulator of this signalling.

To further address the functional consequences of a possible link between ErbB2 and IGFBP3 regulation and a possible role in breast cancer, cell-based assays were performed in the ErbB2-overexpressing and invasive breast cancer cell line SKBR3 after knocking down ErbB2 and IGFBP3 expression. Knockdown of ErbB2 expression $(>95 \%)$ resulted in reduced cell invasion through matrigel (Fig. 9A), reduced proliferation (Fig. 9B) and reduced anchorage-independent colony formation (Fig. 9C), confirming the dependence of this cell line on ErbB2 overexpression for its transformed phenotype. Conversely, siRNA-mediated knockdown of IGFBP3 in these cells $(\sim 50 \%)$, resulted in increased $(\sim 2.3$-fold) invasion (Fig. 9A) and increased ( 1.75-fold) anchorage-independent colony formation (Fig. 9C), whilst proliferation in normal media was not significantly altered (Fig. 9B). We conclude that IGFBP3 is an inhibitor of tumourigenic phenotype and that ErbB2 may promote transformation, at least in part, through suppression of IGFBP3 expression and promotion of IGF1-dependent signalling.

\section{Discussion}

This study has identified genes whose differential expression may contribute to ErbB2-dependent transformation and which define common and specific signalling events induced through EGFR and ErbB3 receptorcontaining complexes. Although we and others have previously examined ErbB2-dependent gene expression changes in the same cell model, and find overlap in the genes identified $[37,38]$, to the best of our knowledge, this is the first study to simultaneously investigate longterm ErbB2- and GF-dependent gene expression using ligands that activate specific ErbB receptor complexes in the same cell system. A number of gene expression changes were further validated using qRT-PCR and we report a good correlation between the datasets, indicating the robustness of the microarray protocol employed.

There were significantly more HRG-responsive genes than EGF-responsive genes and in many cases the HRG response was elevated in the ErbB2-overexpressing cells. This is likely to be a consequence of the higher expression of ErbB2 and ErbB3 in these cells [32] and the preferred heterodimerzation of these receptors [3-6], which would act to augment the response to HRG. We do not think that ErbB4 (also a HRG $\beta 1$ receptor) plays a major role in orchestrating signalling events in this cell system, since it appears to be expressed at very low levels, if at 
A
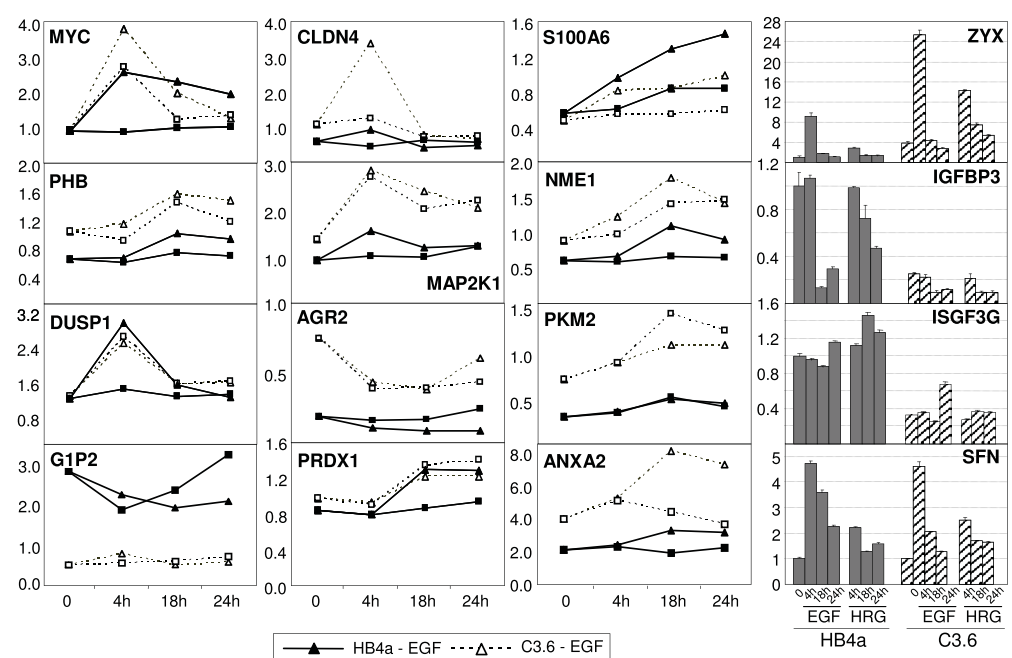

B

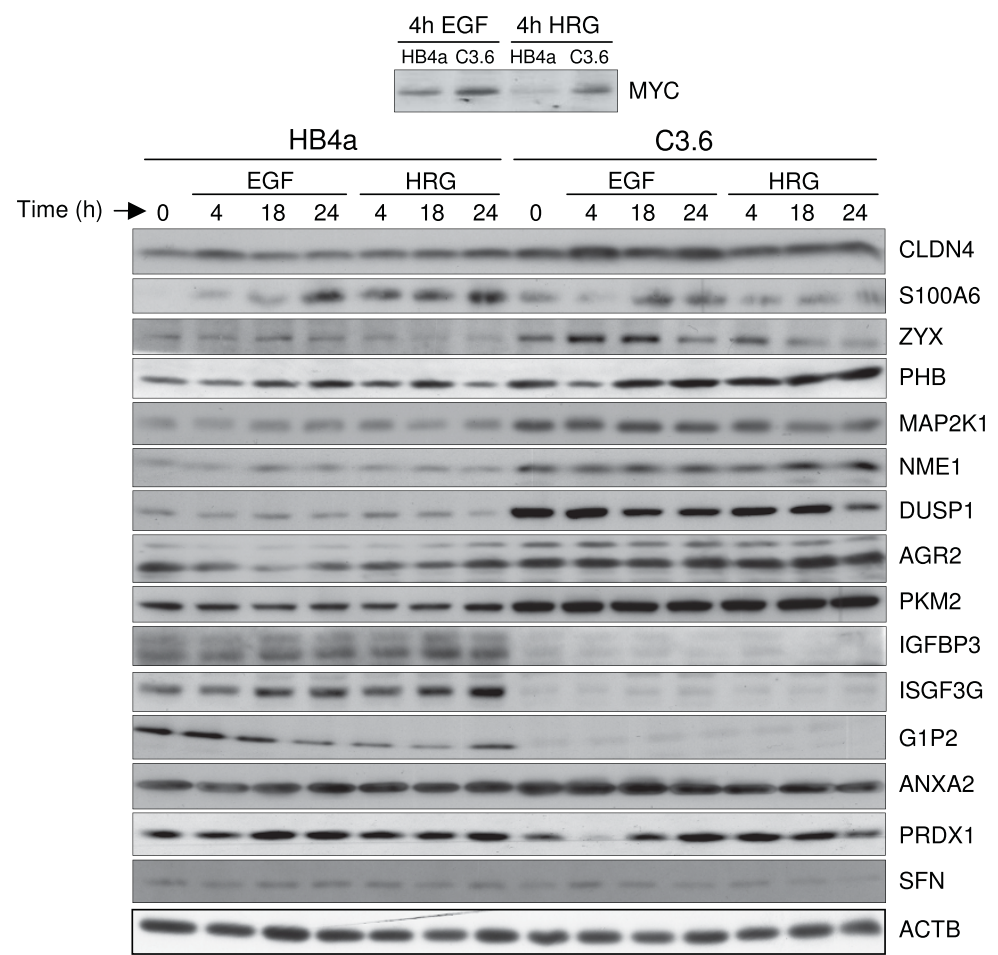

Figure 6 Immunoblot validation of differentially expressed genes. A. Relative gene expression for 16 selected genes by microarray or real time RT-PCR analysis. B. Protein expression for these gene products by immunoblotting. Representative blots from 3-5 independent experiments are shown, including a beta-actin loading control. Myc protein expression was only examined at the $4 \mathrm{hr}$ timepoint and was not detected at other time-points. Relative quantification of immunoblotting data is shown in Additional file 6.

all, in these cell lines (data not shown). Although HRGinduced expression was generally of a lower magnitude than for EGF, it was often sustained compared to EGF, consistent with our previous finding that HRG-dependent mitogenic signalling is sustained in these cells [32]. Such temporal differences may be connected with differential rates of receptor or signal down-regulation, but also highlight the fact that the two growth factors initiate diverse responses which are likely to be relevant in vivo. Genes induced robustly by HRG (ZNF236, ZFP36L1, ZFP36L2, MADH4, TRIO, HMGCR, SLC16A1, SLPI, GYS1, SFRS5, CTNND1, LCAT, LYN, STAT1, KRT15, C20orf16 and FN1) are likely candidates for regulation by the PI3K/Akt pathway which is 


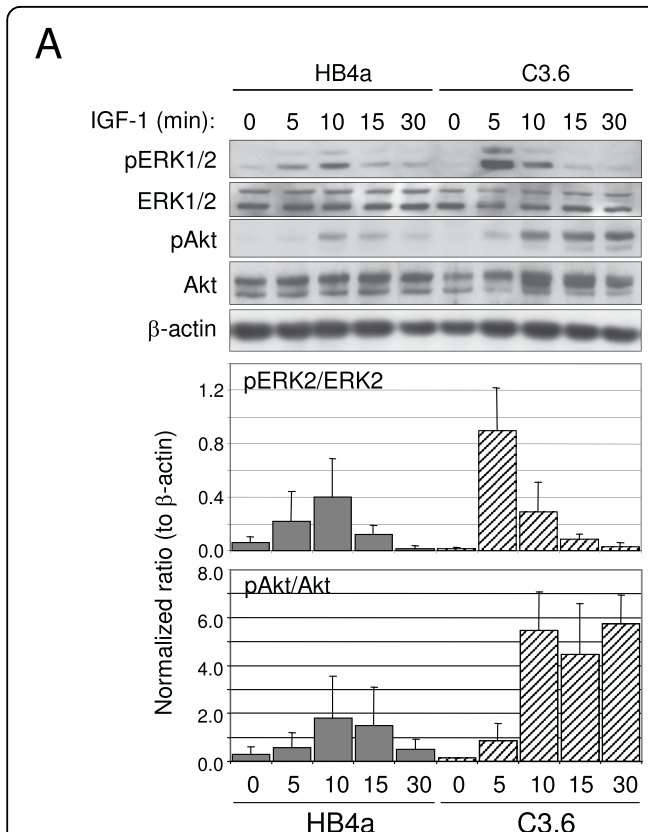

B

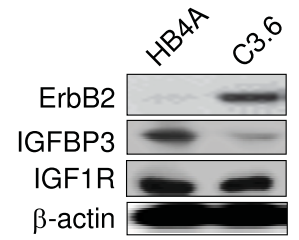

C

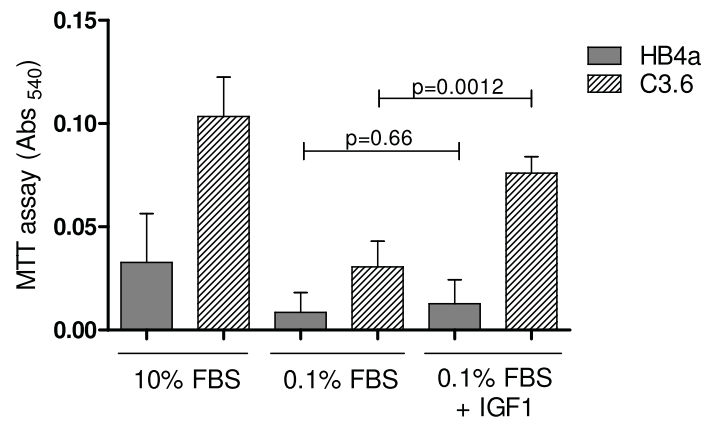

Figure 7 ErbB2-enhances IGF1 signalling and proliferation in the HMLEC system. A. Cells were starved of serum for $48 \mathrm{hrs}$ and then stimulated with $25 \mathrm{ng} / \mathrm{mL}$ IGF1 for the indicated times. Activation of ERK1/2 and Akt was assessed by immunoblotting with phospho-specific antibodies and protein levels checked by reprobing membranes with non-phospho-specific and beta-actin antibodies. Blotting data was quantified by densitometry. Intensities for each band were normalized to the actin band in that lane and the ratios pAkt/Akt and pERK2/ERK2 calculated. Normalized ratios were then averaged from 3 independent blots and plotted using standard deviation as the error. B. Levels of ErbB2, IGFBP3 and IGF1R in HB4a and C3.6 cells were assessed by immunoblotting. C. MTT proliferation assays were carried out on HMLECs in media supplemented with $10 \% \mathrm{FBS}, 0.1 \% \mathrm{FBS}$ and $0.1 \%$ FBS plus $25 \mathrm{ng} / \mathrm{mL}$ IGF1 over a period of 48 hrs.
A

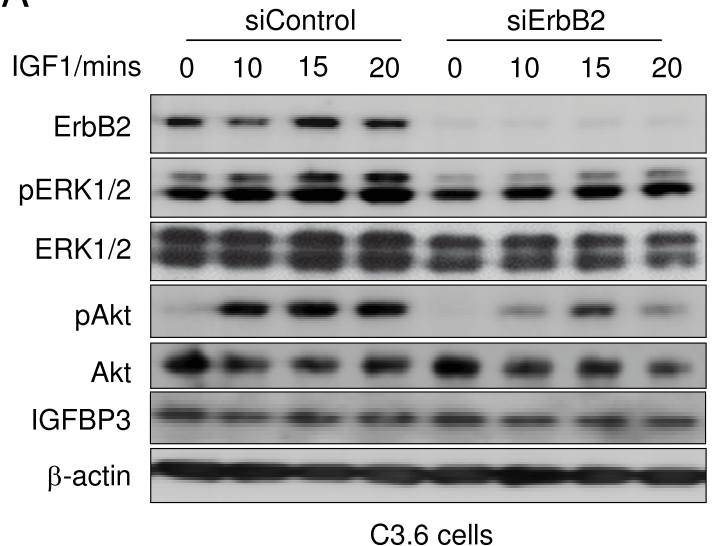

B

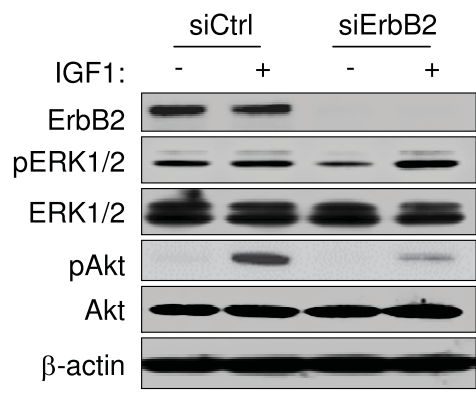

C3.6 cells

C

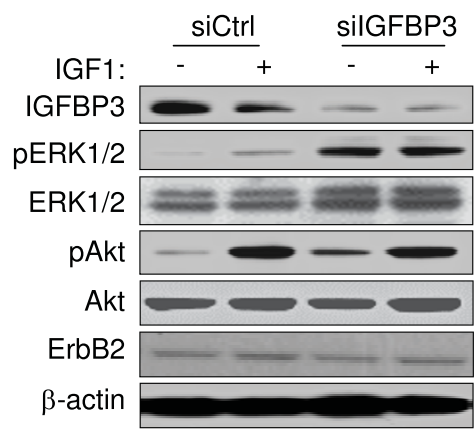

HB4a cells

Figure 8 Effect of siRNA-mediated knockdown of ErbB2 expression on IGF1-stimulated signalling. A. Control siRNA and siErbB2-transfected C3.6 cells were serum starved for 48 hrs and then stimulated with $25 \mathrm{ng} / \mathrm{mL}$ IGF1 for the indicated times. Activation of ERK $1 / 2$ and Akt was assessed by immunoblotting with phospho-specific antibodies and protein levels checked by reprobing membranes with non-phospho-specific, ErbB2, IGFBP3 and beta-actin antibodies. B. Control siRNA and siErbB2-transfected C3.6 cells were serum starved for $48 \mathrm{hrs}$ and then stimulated with $25 \mathrm{ng} /$ mL IGF1 for 20 min (+) or left unstimulated (-). Lysates were immunoblotted as in A. C. Control siRNA and silGFBP3-transfected HB4a cells were serum starved for 48 hrs and then stimulated with $25 \mathrm{ng} / \mathrm{mL}$ IGF1 for $20 \mathrm{~min}$ (+) or left unstimulated (-). Lysates were immunoblotted as in $\mathrm{A}$. 
A

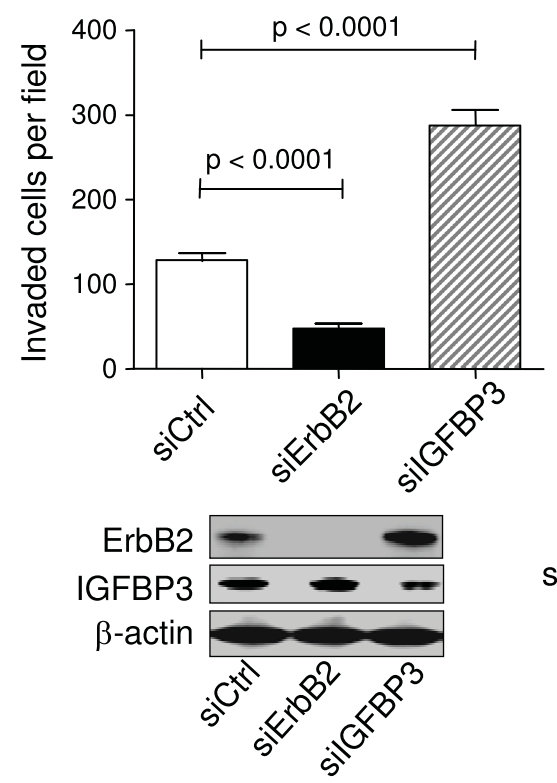

siCtrl

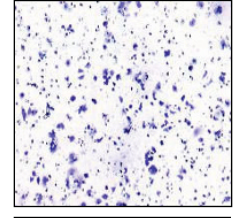

siErbB2

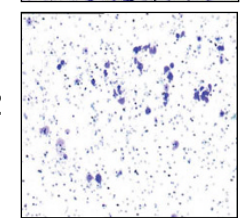

silGFBP3

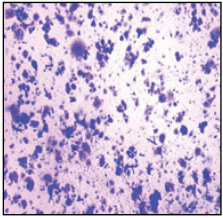

B

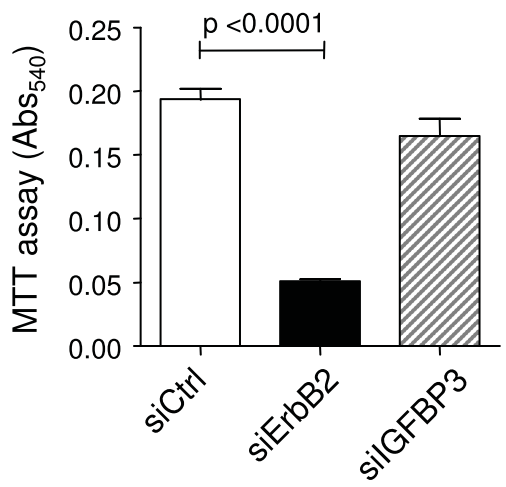

C
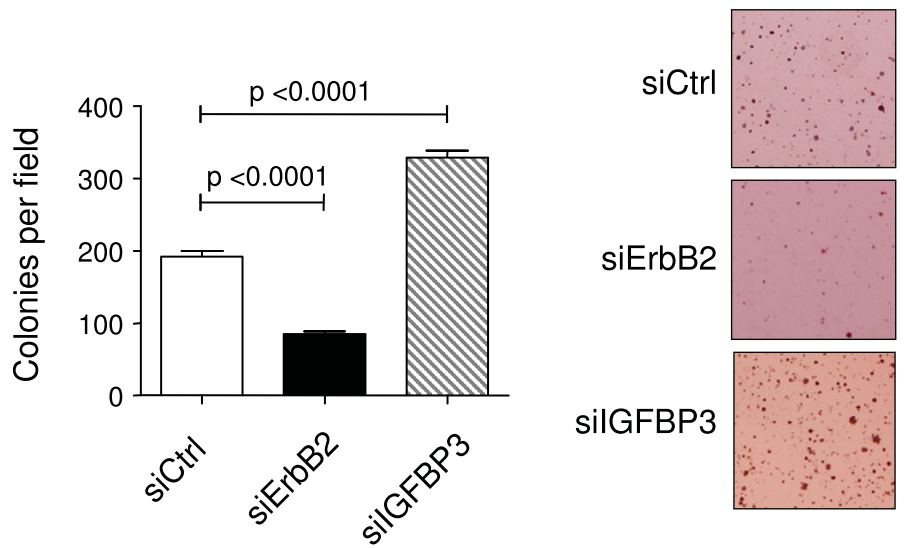

Figure 9 Effect of siRNA-mediated knockdown of ErbB2 and IGFBP3 expression on invasiveness, proliferation and anchorage independent colony formation in SKBR3 cells. A. Control siRNA, siErbB2- and silGFBP3-transfected SKBR3 cells were subjected to a Matrigelbased invasion assay as described in the Methods section. The graph shows the number of invaded cells per field for each condition. Images of stained invaded cells are shown on the right. Knockdowns were confirmed by immunoblotting. B. An MTT-based proliferation assay was carried out on control siRNA, siErbB2- and silGFBP3-transfected SKBR3 cells in complete media over 48 hrs. C. Control siRNA, siErbB2- and silGFBP3transfected SKBR3 cells were assayed for anchorage-independent growth using a soft agar colony forming assay (see Methods section). The graph shows the average number of colonies per field, whilst the images show representative microscopy fields. 
potently activated by HRG through ErbB2-ErbB3 heterodimers $[7,8]$. Since HRG expression itself correlates with tumourigenicity and metastasis in breast cancer cells lines $[39,40]$, it will be interesting to assess whether the induction of these genes is affected by chemical inhibition of the PI3K pathway, or whether such inhibitors would make clinically useful therapeutics for breast cancer treatment.

Notably, a group of EGF-specific genes (e.g. AREG, S100A2 and CTSC) were induced exclusively in the HB4a cells, potentially through EGFR homodimers which predominate in these cells [32]. One of these genes, AREG, is a ligand of EGFR itself, suggesting that EGF could drive autocrine signalling to enhance EGFspecific responses. Members of the MT family were also potently induced by EGF. Whilst induction of MT1 expression by EGF has been shown in rat hepatocytes [41], this is the first report of MT1 (and MT3) induction by EGF in human epithelial cells. Since the altered expression of MT family members has been implicated in neoplasia and drug resistance [42,43], it will be interesting to investigate whether MT expression is linked to deregulated GF signalling in cancer.

Many of the identified genes have been previously implicated in tumour progression, found to be aberrantly expressed in different tumour types and/or to be linked with poor prognosis, hyper-proliferation, cell survival or tumour invasiveness. Our findings suggest that dysregulated ErbB signalling can account for changes in the expression of these genes, and may thus contribute to the establishment and progression of ErbB2-overexpressing breast tumours. For example, of the genes induced by both GFs and augmented by ErbB2, the proto-oncogenic transcription factor MYC has been associated with many forms of cancer often indicating poor prognosis [44]. Importantly, patient survival was significantly reduced in breast cancers where MYC and ErbB2 are co-amplified [45]. The MYC-induced glycoprotein EMP1 was also similarly regulated and whilst its function is unknown, it has reported tumourigenic activity [46] and was identified as a marker of gefinitib-resistance in xenograft models [47]. Thus, one possible scenario that warrants further investigation is that EMP1 acts in concert with MYC to promote ErbB2dependent proliferation and drug resistance. A pattern of ErbB2-augmented GF-induction was also observed for other genes known to be involved in proliferation, autocrine signalling and anti-apoptosis (e.g. ATF4, FOSL1, IER3, MAP2K1/MEK1, MAP2K3/MEK3, PDGF, TNFAIP3, VEGF) and it is possible that these changes contribute to the reported hyper-proliferative phenotype of these ErbB2-overexpressing cells [31,32]. Induction of the pro-angiogenic factor VEGF is particularly relevant to tumour progression and confirms previous data
$[48,49]$. Notably, VEGF expression was shown to depend upon ATF4 expression under certain conditions [50] and we hypothesize that such a regulatory circuit exists in these cells, whereby ErbB2-augmented GF signalling would promote VEGF expression through up-regulation of ATF4. The induction of some genes was perhaps surprising given their reported functions. GADD45A, SFN and the dual-specificity phosphatases DUSP1/MKP1 and DUSP5 were induced by GF treatment and are involved in genotoxic stress-induced growth arrest [51], p53dependent negative regulation of $\mathrm{G} 2 / \mathrm{M}$ progression [52] and down-regulation of MAPK signalling, respectively [53]. We propose that these may be negative feedback mechanisms adapted to self-regulate proliferative signalling.

Conversely, the down-regulation of genes with antiproliferative functions identifies mechanisms by which increased ErbB2 signalling may promote proliferation and survival. Examples include the multiple ISGs that were identified and IGFBP3. G1P2/ISG15 was the most down-regulated gene in the dataset. Like ubiquitin, G1P2 is conjugated to proteins in a process called ISGylation which appears to modulate protein activity during the immune response and signalling [54]. The other ISGs were UBE2L6 (the proposed E2 enzyme for ISGylation [55]), IFIT1, IFITM1, IFITM2, OAS1 and ISGF3G/p48/IRF9. Notably, ISGF3G is a component of a transcription factor complex that with STAT1 and STAT2 controls type I IFN-mediated induction of ISGs containing interferon-stimulated regulatory elements (ISREs) [56]. The lowered expression of ISGF3G could thus account for the down-regulation of the other ISGs in the ErbB2-overexpressing cells, as suggested by our previous work [38]. Whilst the ISGs were induced by IFN treatment in the HMLECs, induction of ISGF3G (particularly with IFN $\gamma$ ) was blocked by GF co-treatment, revealing a possible cross-talk between the IFN and ErbB signalling pathways (data not shown). Although preliminary, our data suggested an inverse correlation between ErbB2 and ISG expression, supporting a role for repressed basal ISG expression in the pathogenesis of ErbB2-dependent breast cancer.

IGFBP3 mRNA and protein expression were both markedly lower in the ErbB2-overexpressing cells, whilst mRNA levels were decreased by GF treatment, particularly in the parental cells. Given IGFBP3's putative role as a negative regulator of IGF1 signalling [35], its antiproliferative role [57] and the negative correlation between serum IGFBP3 levels and cancer risk [58-60], we investigated a possible link between its expression and IGF1 signalling. We found that IGF1-mediated ERK and Akt activation and proliferation were increased in the ErbB2-overexpressing cells and that the signalling effect was reversed by siRNA-mediated knockdown of 
ErbB2. The mechanism by which this occurs is unclear, although does not involve altered IGF1R expression, and may be mediated through interaction between ErbB receptors and IGF1R as previously reported in other cell models [61-63]. ErbB2 may also down-regulate IGFBP3 expression to promote IGF1 signalling. We propose that ErbB2-dependent suppression of IGFBP3 expression is a long-term adaptive response and would be the reason why IGFBP3 protein levels were not affected by transient ErbB2 knockdown. We speculate that this may be due to IGFBP3 promoter methylation, as previously reported for other cancers $[64,65]$. In the C3.6 cells, IGFBP3 expression is suppressed, allowing maximal IGF1 signalling through ErbB2-IGF1R interaction [61-63]. Knocking down ErbB2 in these cells therefore does not affect IGFBP3 levels, but abrogates IFG1 signalling. In HB4a cells, IGF1 signalling is restricted by normal IGFBP3 expression with knockdown of IGFBP3 enhancing basal ERK1/2 and Akt activation, thus supporting its role as a negative regulator of proliferation and survival. Although reduced IGFBP3 expression did not affect acute IGF1 triggering, our data partly support findings in primary and immortalized human esophageal cells, where EGF-mediated down-regulation of IGFBP3 was shown to determine cellular response to IGF1 [66]. However, this effect may be mediated by the as yet unknown IGF1-independent actions of IGFBP3 (reviewed in $[67,68]$ )

The observed increases in invasiveness and anchorageindependent growth of ErbB2-overexpressing SKBR3 cells following knockdown of IGFBP3 supports a role for IGFBP3 as a negative regulator of cellular transformation in breast cancer and we propose that its downregulation is a mechanism whereby ErbB2 promotes tumour cell growth through increased IGF1-dependent proliferation, survival and invasion. Indeed, a requirement for IGF1 in EGF-mediated cell cycle progression has been shown in primary murine mammary epithelial cells [69]. Whilst an attractive model, other studies report that IGFBP3 can potentiate EGF-stimulated proliferation in MCF10A cells [70] and that IGFBP3 expression is associated with growth stimulation of T47D human breast cancer cells [71]. These differences may be explained by cell type-specific effects and are possibly dependent upon the extent of interaction with the ErbB receptor system [71]. Future experiments should explore the effects of overexpressing IGFBP3 on IGF1 signalling, proliferation, survival and invasion and to investigate the level of IGFBP3 promoter methylation in this cell system.

We have previously reported a high correlation between mRNA and protein expression for a subset of genes in these cell lines [38], and a previous proteomic study found reduced expression of GSTP1, PRDX5 and
USP14 and increased expression of KRT13, ALDH1A3 and NME1 in the C3.6 cells [72], in agreement with the mRNA data presented here. In the present study, the mRNA expression of several targets (MYC, CLDN4, S100A6, ZYX, PHB, MAP2K1, NME1, AGR2, PKM2, IGFBP3, ISGF3G, G1P2 and ANXA2) correlated with altered protein expression, signifying that these changes are likely to be functionally relevant. However, correlation between protein and mRNA expression was not apparent for some targets in response to the GF treatments. For example, the repression of IGFBP3 mRNA by GF treatment was not confirmed at the protein level and neither was induction of DUSP1 or SFN. This suggests that the IGFBP3 protein may be relatively stable over the time course of the assay or that the DUSP1 and SFN mRNAs are not translated. Such post-transcriptional regulatory mechanisms are likely to be important, and whilst some mRNA changes appear to be redundant, they may be relevant in other circumstances, for example, during development, differentiation or stress.

A relatively large group of genes involved in regulating the cytoskeleton, cell adhesion and motility were identified. Whilst various patterns of gene expression were apparent, genes up-regulated to a greater degree by either GF in the ErbB2-overexpressing cells (ZYX, VIM, VCL, TAGLN, VIL2, PDLIM1, ITGA2, ITGA3, PLAT, PLAUR, SERPINE1 and ANXA2) are perhaps the most interesting, since they may promote the ErbB2-mediated anchorage-independent growth and reduced cellular adhesion previously observed in this cell model system [31,38]. Notably, some of these genes are members of the plasminogen activator system and have been implicated in tumour progression and invasiveness through proteolysis of the extracellular matrix. Indeed, increased levels of PLAUR and SERPINE1 have been associated with poor prognosis in breast cancer patients [73,74]. Our data thus implicates ErbB2-mediated signalling in the regulation of the plasminogen activator system, as well as cell adhesion-related events.

Finally, a number of genes of unknown or poorlydefined function were identified and several were validated. These include BCAR3, CPNE3, CSRP1, HPCAL1, LCP1, MGC10471, NME1, SMAP, ZFP36L1, ZFP36L2 and ZNF236, which were differentially regulated by GF in an ErbB2-dependent manner and AGR2, LOC402057, NPC2, PSCA, S100P and SERF2, which were differentially expressed in an ErbB2-dependent manner. Our data reveals that the expression of these genes can be regulated by ErbB receptor signalling and thus implicates them as possible biomarkers and effectors of ErbB2-dependent tumourigenesis. Indeed, AGR2, LCP1 and S100P overexpression have been previously correlated with breast cancer progression [75-77], and we 
now link the aberrant expression of these genes with ErbB2 expression.

\section{Conclusions}

Fully understanding and characterising the interactions and outcomes of the identified gene expression changes is a huge undertaking and will require additional studies addressing the functional consequences of such changes. However our data provides a valuable resource and a number of testable hypotheses with potentially important implications in GF signalling and ErbB2-dependent tumourigenesis. One assumption of this work is that the measured effects are indeed ErbB2-dependent and not an artefact of clonal selection and variation. With this in mind, future validation work should involve testing of candidate genes in other clones, mammary cell lines or breast tumour samples that overexpress ErbB2 and by RNAi-mediated knockdown of ErbB2 expression to see if the observed effects can be reversed. Indeed, for one candidate, IGFBP3, we demonstrate it to be a negative regulator of transformation using siRNA-dependent knockdown and propose that its down-regulation enhances IGF1-dependent signalling in ErbB2-overexpressing cells.

\section{Additional material}

Additional file 1: List of antibodies, sources and working dilutions used for immunoblotting. This Word DOC displays a list of antibodies, sources and working dilutions used for immunoblotting.

Additional file 2: Full gene lists (775 genes from SAM) grouped by responsiveness to EGF and HRG. This list has hyperlinks to the SOURCE gene database and an excel macro is available upon request for graphical visualization of expression.

Additional file 3: $\mathrm{K}$-means and hierarchical clustering of EGF and HRG-responsive genes. $K$-means clustering was performed as described in Figure 4, with all 4 groups of genes subjected to hierarchical clustering.

Additional file 4: $K$-means and hierarchical clustering of EGF responsive genes. K-means clustering was performed as described in Figure 4 using only the EGF-responsive genes generated by SAM. Groups (iii) and (iv) were then subjected to hierarchical clustering.

Additional file 5: $K$-means and hierarchical clustering of HRG responsive genes. $K$-means clustering was performed as described in Figure 4 using only the HRG-responsive genes generated by SAM. Groups (i) and (iv) were then subjected to hierarchical clustering.

Additional file 6: Relative quantification of immunoblotting data. All membranes were re-probed for beta-actin and densitometry performed on all bands using local background subtraction. Intensities for each band were normalized to the actin band in that lane and normalized values were averaged from 3-5 independent blots and plotted using the standard deviation as the error.

\section{Abbreviations}

GF: growth factor; HRG: heregulin $\beta 1$; HMLEC: human mammary luminal epithelial cell; FCS: foetal calf serum, GRT-PCR: quantitative real time-PCR; siRNA: small interfering RNA; MT: metallothionein; IGF1: insulin-like growth factor 1; ISG: interferon-stimulated gene; IFN: interferon; IGFBP3: Insulin-like growth factor binding protein 3

\section{Declaration of Competing interests}

The authors declare that they have no competing interests.

\section{Authors' contributions}

JW carried out the molecular functional analysis of IGFBP3 and IGF1 signalling and helped to draft the manuscript. MB carried out the microarray experiments and conducted the statistical analysis, GRT-PCR and some of the protein validation work. H-LC conducted preliminary IGF1 signalling work and protein validation, BG participated in microarray data analysis by constructing the Excel macro for visualisation of data and data mining. JT conceived of the study, participated in its design and coordination and also drafted the manuscript. All authors read and approved the final manuscript.

\section{Acknowledgements}

We thank Dr Alan Mackay for his gift of reference RNA and Prof Michael Waterfield for supervision and useful discussion. This work was funded by the Ludwig Institute for Cancer Research and the Association for International Cancer Research (project grant award 05-426) and was partly undertaken at UCLH/UCL who received a proportion of funding from the Department of Health's NIHR Biomedical Research Centres funding scheme.

\section{Author details}

${ }^{1}$ Cancer Proteomics Laboratory, EGA Institute for Women's Health, University College London, Cruciform Building, Gower Street, London, WC1E 6BT, UK. 'Ludwig Institute for Cancer Research, Cruciform Building, Gower Street, London, WC1E 6BT, UK. ${ }^{3}$ Institute of Bioinformatics and Structural Biology, National Tsing Hua University, Hsinchu, Taiwan.

Received: 23 March 2010 Accepted: 14 September 2010 Published: 14 September 2010

\section{References}

1. Yarden Y, Sliwkowski MX: Untangling the ErbB signalling network. Nat Rev Mol Cell Biol 2001, 2(2):127-137.

2. Alroy I, Yarden Y: The ErbB signaling network in embryogenesis and oncogenesis: signal diversification through combinatorial ligandreceptor interactions. FEBS Lett 1997, 410(1):83-86.

3. Graus-Porta DBR, Daly JM, Hynes NE: ErbB-2, the preferred heterodimerization partner of all ErbB receptors, is a mediator of lateral signaling. EMBO J 1997, 16(7):1647-1655.

4. Karunagaran D, Tzahar E, Beerli RR, Chen X, Graus-Porta D, Ratzkin BJ, Seger $R$, Hynes NE, Yarden $Y$ : ErbB-2 is a common auxiliary subunit of NDF and EGF receptors: implications for breast cancer. Embo J 1996, 15(2):254-264

5. Beerli RR, Graus-Porta D, Woods-Cook K, Chen X, Yarden Y, Hynes NE: Neu differentiation factor activation of ErbB-3 and ErbB-4 is cell specific and displays a differential requirement for ErbB-2. Mol Cell Biol 1995, 15(12):6496-6505.

6. Graus-Porta D, Beerli RR, Hynes NE: Single-chain antibody-mediated intracellular retention of ErbB-2 impairs Neu differentiation factor and epidermal growth factor signaling. Mol Cell Biol 1995, 15(3):1182-1191.

7. Soltoff SP, Carraway KL, Prigent SA, Gullick WG, Cantley LC: ErbB3 is involved in activation of phosphatidylinositol 3-kinase by epidermal growth factor. Mol Cell Biol 1994, 14(6):3550-3558.

8. Hellyer NJ, Kim MS, Koland JG: Heregulin-dependent activation of phosphoinositide 3-kinase and Akt via the ErbB2/ErbB3 co-receptor. J Biol Chem 2001, 276(45):42153-42161.

9. Confalonieri S, Salcini AE, Puri C, Tacchetti C, Di Fiore PP: Tyrosine phosphorylation of Eps15 is required for ligand-regulated, but not constitutive, endocytosis. J Cell Biol 2000, 150(4):905-912.

10. Levkowitz G, Klapper LN, Tzahar E, Freywald A, Sela M, Yarden Y: Coupling of the $\mathrm{c}-\mathrm{Cbl}$ protooncogene product to ErbB-1/EGF-receptor but not to other ErbB proteins. Oncogene 1996, 12(5):1117-1125.

11. Sliwkowski MX, Schaefer G, Akita RW, Lofgren JA, Fitzpatrick VD, Nuijens A, Fendly BM, Cerione RA, Vandlen RL, Carraway KL: Coexpression of erbB2 
and erbB3 proteins reconstitutes a high affinity receptor for heregulin. $J$ Biol Chem 1994, 269(20):14661-14665.

12. Pinkas-Kramarski R, Soussan L, Waterman H, Levkowitz G, Alroy I, Klapper L, Lavi S, Seger R, Ratzkin BJ, Sela M, et al: Diversification of Neu differentiation factor and epidermal growth factor signaling by combinatorial receptor interactions. Embo J 1996, 15(10):2452-2467.

13. Holbro T, Beerli RR, Maurer F, Koziczak M, Barbas CF, Hynes NE: The ErbB2/ ErbB3 heterodimer functions as an oncogenic unit: ErbB2 requires ErbB3 to drive breast tumor cell proliferation. Proc Natl Acad Sci USA 2003, 100(15):8933-8938.

14. Ross JS, Fletcher JA: The HER-2/neu Oncogene in Breast Cancer: Prognostic Factor, Predictive Factor, and Target for Therapy. Stem Cells 1998, 16(6):413-428.

15. Slamon DJ, Clark GM, Wong SG, Levin WJ, Ullrich A, McGuire WL: Human breast cancer: correlation of relapse and survival with amplification of the HER-2/neu oncogene. Science 1987, 235(4785):177-182.

16. Slamon DJ, Leyland-Jones B, Shak S, Fuchs H, Paton V, Bajamonde A, Fleming T, Eiermann W, Wolter J, Pegram M, et al: Use of chemotherapy plus a monoclonal antibody against HER2 for metastatic breast cancer that overexpresses HER2. N Engl J Med 2001, 344(11):783-792.

17. Menard S, Pupa SM, Campiglio M, Tagliabue E: Biologic and therapeutic role of HER2 in cancer. Oncogene 2003, 22(42):6570-6578.

18. Paez JG, Janne PA, Lee JC, Tracy S, Greulich H, Gabriel S, Herman P, Kaye FJ, Lindeman N, Boggon TJ, et al: EGFR mutations in lung cancer: correlation with clinical response to gefitinib therapy. Science 2004, 304(5676):1497-1500.

19. El Rayes BF, LoRusso PM: Targeting the epidermal growth factor receptor. Br J Cancer 2004, 91(3):418.

20. Lin NU, Winer EP: New targets for therapy in breast cancer: small molecule tyrosine kinase inhibitors. Breast Cancer Res 2004, 6(5):204-210.

21. Jahanzeb M: Adjuvant trastuzumab therapy for HER2-positive breast cancer. Clin Breast Cancer 2008, 8(4):324-333.

22. Suzuki E, Toi M: Improving the efficacy of trastuzumab in breast cancer. Cancer science 2007, 98(6):767-771.

23. Ahr A, Karn T, Solbach C, Seiter T, Strebhardt K, Holtrich U, Kaufmann M: Identification of high risk breast-cancer patients by gene expression profiling. Lancet 2002, 359(9301):131-132.

24. West $M$, Blanchette $C$, Dressman $H$, Huang E, Ishida S, Spang R, Zuzan $H$, Olson JA Jr, Marks JR, Nevins JR: Predicting the clinical status of human breast cancer by using gene expression profiles. Proc Natl Acad Sci USA 2001, 98(20):11462-11467.

25. Hedenfalk I, Duggan D, Chen Y, Radmacher M, Bittner M, Simon R, Meltzer P, Gusterson B, Esteller M, Kallioniemi OP, et al: Gene-expression profiles in hereditary breast cancer. N Engl J Med 2001, 344(8):539-548.

26. van 't Veer $L$, Dai $H$, van de Vijver MJ, He YD, Hart AA, Mao M, Peterse HL, van der Kooy K, Marton MJ, Witteveen AT, et al: Gene expression profiling predicts clinical outcome of breast cancer. Nature 2002, 415(6871):530-536.

27. Sorlie T, Perou CM, Tibshirani R, Aas T, Geisler $\mathrm{S}$, Johnsen $H$, Hastie $T$, Eisen $M B$, van de Rijn $M$, Jeffrey $S S$, et al: Gene expression patterns of breast carcinomas distinguish tumor subclasses with clinical implications. PNAS 2001, 98(19):10869-10874.

28. Sorlie T, Tibshirani R, Parker J, Hastie T, Marron JS, Nobel A, Deng S, Johnsen H, Pesich R, Geisler $\mathrm{S}$, et al: Repeated observation of breast tumor subtypes in independent gene expression data sets. Proc Natl Acad Sci USA 2003, 100(14):8418-8423.

29. Perou CM, Sorlie T, Eisen MB, van de Rijn M, Jeffrey SS, Rees CA, Pollack JR, Ross DT, Johnsen H, Akslen LA, et al: Molecular portraits of human breast tumours. Nature 2000, 406(6797):747-752.

30. Stamps AC, Davies SC, Burman J, O'Hare MJ: Analysis of proviral integration in human mammary epithelial cell lines immortalized by retroviral infection with a temperature-sensitive SV40 T-antigen construct. Int J Cancer 1994, 57(6):865-874.

31. Harris RA, Eichholtz TJ, Hiles ID, Page MJ, O'Hare MJ: New model of ErbB-2 over-expression in human mammary luminal epithelial cells. Int $J$ Cancer 1999, 80(3):477-484.

32. Timms JF, White SL, O'Hare MJ, Waterfield MD: Effects of ErbB-2 overexpression on mitogenic signalling and cell cycle progression in human breast luminal epithelial cells. Oncogene 2002, 21(43):6573-6586.
33. Yang YH, Dudoit S, Luu P, Lin DM, Peng V, Ngai J, Speed TP: Normalization for CDNA microarray data: a robust composite method addressing single and multiple slide systematic variation. Nucleic Acids Res 2002, 30(4):e15.

34. Tusher VG, Tibshirani R, Chu G: Significance analysis of microarrays applied to the ionizing radiation response. Proc Natl Acad Sci USA 2001, 98(9):5116-5121.

35. Ricort JM: Insulin-like growth factor binding protein (IGFBP) signalling Growth Horm IGF Res 2004, 14(4):277-286.

36. Helle SI: The insulin-like growth factor system in advanced breast cancer. Best Pract Res Clin Endocrinol Metab 2004, 18(1):67-79.

37. Mackay A, Jones $C$, Dexter T, Silva RL, Bulmer $K$, Jones A, Simpson $P$, Harris RA, Jat PS, Neville AM, et al: CDNA microarray analysis of genes associated with ERBB2 (HER2/neu) overexpression in human mammary luminal epithelial cells. Oncogene 2003, 22(17):2680-2688.

38. White SL, Gharbi S, Bertani MF, Chan HL, Waterfield MD, Timms JF: Cellular responses to ErbB-2 overexpression in human mammary luminal epithelial cells: comparison of mRNA and protein expression. $\mathrm{Br} J$ Cancer 2004, 90(1):173-181.

39. Tsai MS, Shamon-Taylor LA, Mehmi I, Tang CK, Lupu R: Blockage of heregulin expression inhibits tumorigenicity and metastasis of breast cancer. Oncogene 2003, 22(5):761-768.

40. Atlas E, Cardillo M, Mehmi I, Zahedkargaran H, Tang C, Lupu R: Heregulin is sufficient for the promotion of tumorigenicity and metastasis of breast cancer cells in vivo. Mol Cancer Res 2003, 1(3):165-175.

41. Moffatt P, Plaa GL, Denizeau F: Induction of metallothionein gene expression by epidermal growth factor and its inhibition by transforming growth factor-beta and dexamethasone in rat hepatocytes. Hepatology 1995, 21(4):1038-1044.

42. Goulding H, Jasani B, Pereira H, Reid A, Galea M, Bell JA, Elston CW, Robertson JF, Blamey RW, Nicholson RA: Metallothionein expression in human breast cancer. Br J Cancer 1995, 72(4):968.

43. Theocharis SE, Margeli AP, Klijanienko JT, Kouraklis GP: Metallothionein expression in human neoplasia. Histopathology 2004, 45(2):103.

44. Pelengaris $\mathrm{S}$, Khan M: The many faces of c-MYC. Arch Biochem Biophys 2003, 416(2):129-136.

45. Cuny M, Kramar A, Courjal F, Johannsdottir V, lacopetta B, Fontaine H, Grenier J, Culine S, Theillet C: Relating genotype and phenotype in breast cancer: an analysis of the prognostic significance of amplification at eight different genes or loci and of p53 mutations. Cancer Res 2000, 60(4):1077-1083.

46. Ben-Porath I, Yanuka O, Benvenisty N: The tmp gene, encoding a membrane protein, is a c-Myc target with a tumorigenic activity. Mol Cell Biol 1999, 19(5):3529-3539.

47. Jain A, Tindell CA, Laux I, Hunter JB, Curran J, Galkin A, Afar DE, Aronson N, Shak S, Natale RB, et al: Epithelial membrane protein-1 is a biomarker of gefitinib resistance. Proc Natl Acad Sci USA 2005, 102(33):11858-11863.

48. Xiong S, Grijalva R, Zhang L, Nguyen NT, Pisters PW, Pollock RE, Yu D: Upregulation of vascular endothelial growth factor in breast cancer cells by the heregulin-beta1-activated p38 signaling pathway enhances endothelial cell migration. Cancer Res 2001, 61(4):1727-1732.

49. Yen L, You XL, Al Moustafa AE, Batist G, Hynes NE, Mader S, Meloche S, Alaoui-Jamali MA: Heregulin selectively upregulates vascular endothelial growth factor secretion in cancer cells and stimulates angiogenesis. Oncogene 2000, 19(31):3460-3469.

50. Roybal CN, Yang S, Sun CW, Hurtado D, Vander Jagt DL, Townes TM, Abcouwer SF: Homocysteine increases the expression of vascular endothelial growth factor by a mechanism involving endoplasmic reticulum stress and transcription factor ATF4. J Biol Chem 2004, 279(15):14844-14852.

51. Zhan Q: Gadd45a, a p53- and BRCA1-regulated stress protein, in cellular response to DNA damage. Mutation research 2005, 569(1-2):133-143.

52. Hermeking H, Lengauer C, Polyak K, He TC, Zhang L, Thiagalingam S, Kinzler KW, Vogelstein B: 14-3-3 sigma is a p53-regulated inhibitor of G2/ M progression. Mol Cell 1997, 1(1):3-11.

53. Faroog A, Zhou MM: Structure and regulation of MAPK phosphatases. Cell Signal 2004, 16(7):769-779.

54. Schwartz DC, Hochstrasser M: A superfamily of protein tags: ubiquitin, SUMO and related modifiers. Trends Biochem Sci 2003, 28(6):321-328.

55. Zhao C, Beaudenon SL, Kelley ML, Waddell MB, Yuan W, Schulman BA, Huibregtse JM, Krug RM: The UbcH8 ubiquitin E2 enzyme is also the E2 
enzyme for ISG15, an IFN-alpha/beta-induced ubiquitin-like protein. Proc Natl Acad Sci USA 2004, 101(20):7578-7582.

56. Stark GR, Kerr IM, Williams BR, Silverman RH, Schreiber RD: How cells respond to interferons. Annu Rev Biochem 1998, 67:227-264.

57. Baxter RC: Signalling pathways involved in antiproliferative effects of IGFBP-3: a review. Mol Pathol 2001, 54(3):145-148.

58. Chan JM, Stampfer MJ, Giovannucci E, Gann PH, Ma J, Wilkinson P, Hennekens CH, Pollak M: Plasma insulin-like growth factor-I and prostate cancer risk: a prospective study. Science 1998, 279(5350):563-566.

59. Ma J, Pollak MN, Giovannucci E, Chan JM, Tao Y, Hennekens $\mathrm{CH}_{\text {, }}$ Stampfer MJ: Prospective study of colorectal cancer risk in men and plasma levels of insulin-like growth factor (IGF)-I and IGF-binding protein-3. J Natl Cancer Inst 1999, 91(7):620-625.

60. Yu H, Spitz MR, Mistry J, Gu J, Hong WK, Wu X: Plasma levels of insulin-like growth factor-I and lung cancer risk: a case-control analysis. J Natl Cancer Inst 1999, 91(2):151-156.

61. Balana ME, Labriola L, Salatino M, Movsichoff F, Peters G, Charreau EH, Elizalde PV: Activation of ErbB-2 via a hierarchical interaction between ErbB-2 and type I insulin-like growth factor receptor in mammary tumor cells. Oncogene 2001, 20(1):34-47.

62. Nahta R, Yuan LX, Zhang B, Kobayashi R, Esteva FJ: Insulin-like growth factor-l receptor/human epidermal growth factor receptor 2 heterodimerization contributes to trastuzumab resistance of breast cancer cells. Cancer Res 2005, 65(23):11118-11128.

63. Huang X, Gao L, Wang S, McManaman JL, Thor AD, Yang X, Esteva FJ, Liu B: Heterotrimerization of the growth factor receptors erbB2, erbB3, and insulin-like growth factor-i receptor in breast cancer cells resistant to herceptin. Cancer Res 2010, 70(3):1204-1214.

64. Dar AA, Majid S, Nosrati M, de Semir D, Federman S, Kashani-Sabet M: Functional modulation of IGF-binding protein-3 expression in melanoma. J Invest Dermatol 2010, 130(8):2071-2079.

65. Torng PL, Lin CW, Chan MW, Yang HW, Huang SC, Lin CT: Promoter methylation of IGFBP-3 and $\mathrm{p} 53$ expression in ovarian endometrioid carcinoma. Molecular cancer 2009, 8:120.

66. Takaoka M, Smith CE, Mashiba MK, Okawa T, Andl CD, El-Deiry WS, Nakagawa H: EGF-mediated regulation of IGFBP-3 determines esophageal epithelial cellular response to IGF-I. American journal of physiology 2006, 290(2):G404-416.

67. Yamada PM, Lee KW: Perspectives in mammalian IGFBP-3 biology: local vs. systemic action. Am J Physiol Cell Physiol 2009, 296(5):C954-976.

68. Perks CM, Holly JM: IGF binding proteins (IGFBPs) and regulation of breast cancer biology. J Mammany Gland Biol Neoplasia 2008, 13(4):455-469.

69. Stull MA, Richert MM, Loladze AV, Wood TL: Requirement for IGF-I in epidermal growth factor-mediated cell cycle progression of mammary epithelial cells. Endocrinology 2002, 143(5):1872-1879.

70. Martin JL, Weenink SM, Baxter RC: Insulin-like Growth Factor-binding Protein-3 Potentiates Epidermal Growth Factor Action in MCF-10A Mammary Epithelial Cells. INVOLVEMENT OF p44/42 AND p38 MITOGENACTIVATED PROTEIN KINASES. JBio/Chem 2003, 278(5):2969.

71. Butt AJ, Martin JL, Dickson KA, McDougall F, Firth SM, Baxter RC: Insulin-like growth factor binding protein-3 expression is associated with growth stimulation of T47D human breast cancer cells: the role of altered epidermal growth factor signaling. J Clin EndocrinolMetab 2004, 89(4):1950.

72. Chan HL, Gharbi S, Gaffney PR, Cramer R, Waterfield MD, Timms JF: Proteomic analysis of redox- and ErbB2-dependent changes in mammary luminal epithelial cells using cysteine- and lysine-labelling two-dimensional difference gel electrophoresis. Proteomics 2005, 5(11):2908-2926

73. Han B, Nakamura M, Mori I, Nakamura Y, Kakudo K: Urokinase-type plasminogen activator system and breast cancer (Review). Oncol Rep 2005, 14(1):105-112.

74. Andreasen PA, Egelund R, Petersen $\mathrm{HH}$ : The plasminogen activation system in tumor growth, invasion, and metastasis. Cell Mol Life Sci 2000 57(1):25-40.

75. Liu D, Rudland PS, Sibson DR, Platt-Higgins A, Barraclough R: Human homologue of cement gland protein, a novel metastasis inducer associated with breast carcinomas. Cancer Res 2005, 65(9):3796-3805.
76. Lin CS, Chen ZP, Park T, Ghosh K, Leavitt J: Characterization of the human L-plastin gene promoter in normal and neoplastic cells. J Biol Chem 1993, 268(4):2793-2801.

77. Guerreiro Da Silva ID, Hu YF, Russo IH, Ao X, Salicioni AM, Yang X, Russo J: S100P calcium-binding protein overexpression is associated with immortalization of human breast epithelial cells in vitro and early stages of breast cancer development in vivo. Int J Oncol 2000, 16(2):231-240.

78. Gharbi S, Gaffney P, Yang A, Zvelebil MJ, Cramer R, Waterfield MD, Timms JF: Evaluation of two-dimensional differential gel electrophoresis for proteomic expression analysis of a model breast cancer cell system. Mol Cell Proteomics 2002, 1(2):91-98.

\section{Pre-publication history}

The pre-publication history for this paper can be accessed here: http://www.biomedcentral.com/1471-2407/10/490/prepub

\section{doi:10.1186/1471-2407-10-490}

Cite this article as: Worthington et al:: Transcriptional profiling of ErbB signalling in mammary luminal epithelial cells - interplay of ErbB and IGF1 signalling through IGFBP3 regulation. BMC Cancer 2010 10:490.

\section{Submit your next manuscript to BioMed Central and take full advantage of:}

- Convenient online submission

- Thorough peer review

- No space constraints or color figure charges

- Immediate publication on acceptance

- Inclusion in PubMed, CAS, Scopus and Google Scholar

- Research which is freely available for redistribution

Submit your manuscript at www.biomedcentral.com/submit
C Biomed Central 